\title{
Species level variation in coccolithophores
}

Markus Geisen ${ }^{1,2}$, Jeremy R. Young ${ }^{2}$, Ian Probert ${ }^{3}$, Alberto G. Sáez ${ }^{4}$, KarlHeinz Baumann ${ }^{5}$, Claudia Sprengel ${ }^{1}$, Jörg Bollmann ${ }^{6}$, Lluïsa Cros $^{7}$, Colomban de Vargas ${ }^{8}$, and Linda K. Medlin ${ }^{1}$

${ }^{1}$ Pelagic Ecosystems, Alfred Wegener Institute for Polar and Marine Research, Am Handelshafen 12, D-27570 Bremerhaven, Germany. mgeisen@awi-bremerhaven.de, lmedlin@awi-bremerhaven.de, csprengel@awi-bremerhaven.de

2 Palaeontology Department, The Natural History Museum, Cromwell Road, London SW7 5BD, GB. j.young@nhm.ac.uk

${ }^{3}$ Laboratory of Marine Biology and Biotechnology, University of Caen, F-14032 Caen, France. IanProbert@hotmail.com

${ }^{4}$ Department of Biological Sciences, Imperial College London, Silwood Park Campus, Ascot, Berkshire SL5 7PY, England. a.saez@imperial.ac.uk

5 Department of Geosciences, University Bremen, Postfach 330440, D-28334 Bremen, Germany.baumann@uni-bremen.de

${ }^{6}$ Geological Institute, Swiss Federal Institute of Technology, Sonneggstrasse 5, CH-8092 Zurich, Switzerland. bolle@erdw.ethz.ch

${ }^{7}$ Institut de Ciències del Mar, CMIMA-CSIC, Passeig Marítim de la Barceloneta, 37-49, 08003 Barcelona, Spain. 1luisa@icm.csic.es

${ }^{8}$ Institute for Marine and Coastal Sciences, Rutgers University, New Brunswick, New Jersey, USA.vargas@imcs.rutgers.edu

\section{Abstract}

Coccolithophores are an ideal test group for investigating fine-scale differentiation within the phytoplankton since their taxonomy is rather well-documented and their biomineralised periplasts - the coccoliths - provide a rich suite of qualitative and quantitative morphological characters and a uniquely extensive fossil record. In addition, extant coccolithophore species can be grown in culture and hence are available for studies of morphological variability under controlled conditions, molecular genetic studies and cytological research.

For the CODENET project the following extant species with seemingly global occurrence and spanning the biodiversity of coccolithophores were selected: Coccolithus pelagicus, Calcidiscus leptoporus, Umbilicosphaera sibogae, Syracosphaera pulchra, Gephyrocapsa oceanica, and Helicosphaera carteri. These were used as case studies to elucidate their species level biodiversity. The key merit of our approach was the use of multiple, independent lines of evidence, so as to remove the ambiguity implicit in any one type of study. In each case morphotypes of previously uncertain significance have been shown to represent discrete genotypes and probably well-separated species, with divergence times ranging 
from about 100 kyrs to $>10$ myrs. The evolutionary significance of these results is discussed.

\section{Introduction}

Oceans cover roughly seventy percent of the earth's surface. With few exceptions, minute photosynthetic primary producers such as diatoms, dinoflagellates, silicoflagellates and coccolithophores inhabit the euphotic zone of this vast expanse. This phytoplankton forms the basis of the marine food chain and plays an important role in geochemical cycles. Knowledge of species level biodiversity and speciation is thus important for understanding marine ecology and biogeochemistry. Moreover, for geologists seeking to maximise biostratigraphic and palaeoceanographic data retrieval from fossil assemblages, reliable fine scale taxonomy is critical.

Coccolithophores are a group of marine calcifying algae belonging to the division Haptophyta (Jordan and Chamberlain 1997). The conventional interpretation of coccolithophore systematics is that there are about 120 well-described heterococcolithophore species (Jordan and Green 1994), with, in almost all cases, interoceanic distributions within broad ecological boundaries (Jordan and Kleijne 1994; Young and Bown 1994; Jordan and Chamberlain 1997). A perception of very widely distributed, rather homogeneous species is well supported by geological evidence of synchronous, apparently sympatric evolution across the world oceans and for near synchronous (on scales of less than a few thousand years) extinction events (Chepstow-Lusty et al. 1992; Wei 1993; Wei and Shilan 1996). Research over the past decade via the integration of data from various sources (morphology, life-cycles, and molecular studies) has greatly refined our knowledge of fine scale diversity in this group. This has led to the development of hypotheses of causation in terms of ecophenotypic or genotypic variation. New data have come from different sources, which will subsequently be discussed briefly.

\section{Morphology}

The primary source of data has been morphometric investigation of selected taxa using plankton, sediment trap, culture, surface sediment samples, and often time series studies of geological samples. On the basis of quantifiable morphometric parameters - mostly coccolith size, but also the number of elements (in Calcidiscus spp.) and the bridge angle (in Gephyrocapsa spp.) - this has led to the identification of sub-morphotypes and morphological gradients within species (Bollmann 1997; Knappertsbusch et al. 1997; Knappertsbusch 2000).

In addition to quantitative methods, qualitative morphological data including shield structure, crystallographic axis orientation (Young et al. 1992; Young et al. 1999), suture lines, and ornamentation of coccoliths (Kleijne 1993) have provided an important additional source of information about intra-specific variation. Ex- 
amples include Calcidiscus spp., where the expression of suture lines and the appearance of the zone surrounding the central pore have proved to be crucial for the understanding of the diversity within the genus (Kleijne 1993). In Helicosphaera spp., the stability of fine morphological characters in the central area was validated as a species discriminating feature (Geisen 2003). In Umbilicosphaera spp., mono- versus bicyclic shield structure and central area features were used to differentiate species (Geisen 2003).

\section{Ecological / biogeographical separation}

As the concept of biological species requires reproductive isolation, a sound knowledge of the geographical and ecological ranges of the putative morphotypes is important. Evidence here stems both from the biogeographical mapping of distributions of differing morphologies and from studies of species associations from sediment trap time series. Different factors have been identified: In Coccolithus spp., there appears to be a spatial variation, separating a subarctic species from a temperate species with partially overlapping ranges (Cachao and Moita 2000); in Calcidiscus spp., Renaud and Klaas (2001) have demonstrated a temporal succession of morphologies; and finally the two "pseudo-cryptic" species ("pseudocryptic" speciation is speciation taking place without obvious change in morphology - for a review refer to Knowlton 1993 and references therein) detected in Syracosphaera apparently share the same habitat (Geisen et al. 2002).

\section{Culture studies}

A critical test for the interpretation of fine morphological differences is whether these features are stable in culture. At the most basic level if two monoclonal cultures consistently show different morphologies when grown under similar conditions then we can conclude that this morphological difference is genotypic in origin. Further testing comes from studies of the degree of morphological variation within monoclonal strains grown under varying ecological conditions. Doing this enables assessment of the degree of ecophenotypic variation, which can occur within a single genotype.

This method was first applied to coccolithophores by Young and Westbroek (1991) to assess the different effects of genotypic and ecophenotypic variation in Emiliania huxleyi. However, isolating and maintaining species in clonal cultures is labour intensive and since then further tests have only been performed on $\mathrm{Cal}$ cidiscus leptoporus (Quinn et al. 2003). The CODENET keystone species and a number of additional species isolated during the project have now provided the opportunity for a more detailed study of the morphological variability of coccolithophores in culture. Data here include quantitative and qualitative morphological characters as described above (Geisen 2003). 


\section{Genetic separation}

A set of molecular markers was used to study the extent of genotypic variation between and within recognised morphological species. Different genes from the nucleus and the chloroplast - with varying rates of nucleotide substitution - were sequenced. The slowly evolving nuclear gene $18 \mathrm{~S}$ rDNA was used to quantify inter-specific differences, reconstruct the molecular phylogeny of coccolithophores and other Haptophyta, and infer times of divergence in these groups (e.g. Medlin et al. 1997; Edvardsen et al. 2000; Fujiwara et al. 2001). Within the CODENET project, we used it for the same purposes, extending our analyses to a much larger set of species (Sáez et al. 2003; Sáez et al. this volume). Faster evolving plastid genes have also been used for resolving coccolithophorid and Haptophyta phylogenies: $r b c$ L (Fujiwara et al. 2001) and tufA (Sáez et al. 2003).

In addition to the nuclear $18 \mathrm{~S}$ rDNA, including the very fast-evolving ribosomal internal transcribed spacer region (ITS rDNA), the molecular marker tufA was also sequenced in isolates of the same species, to assess the biological significance of phenotypic variation observed within recognised morphological species (Sáez et al. 2003; de Vargas et al. and Quinn et al. this volume,).

Although DNA has been amplified from single cells using the Polymerase Chain Reaction (PCR) technique (e.g. de Vargas et al. 1999), this has not yet been successfully applied to coccolithophores. So, our molecular work still depends on cultures to produce sufficient cell biomass for DNA amplification. This limits the number of analyses which can be made, but conversely the use of cultures means that detailed morphological analyses can be directly correlated with molecular results. As the number of strains in culture was a limiting factor, our approach was to sample genes from different loci - the chloroplast and the nucleus - to obtain, if possible, concordant results.

Molecular genetic data can be used not only to test whether putative fine-scale morphological variation is genotypic in origin but also to provide estimates of the likely time of divergence. Our data indicate that both $18 \mathrm{~S}$ rDNA and tufA of coccolithophores evolved in a clock-like manner and basic calibration of this record is possible (Sáez et al. 2003). There are substantial uncertainties in any molecular clock estimate, nonetheless, it is possible to use genetic distance data to infer order of magnitude estimates of divergence times and hence to discriminate between possibilities such as that pairs of genotypes diverged within the last $1 \mathrm{Ma}$ or several Ma ago.

\section{Life-cycles and holococcolith phase differentiation}

A fifth source of data has come from recognition of alternate life-cycle phases. It is now clear that the typical life-cycle of coccolithophores consists of independent haploid and diploid phases, both of which are capable of indefinite asexual reproduction (Billard and Inouye this volume). Both phases usually produce coccoliths but via distinctly different biomineralisation processes resulting in consistent structural differences. In the diploid phase biomineralisation occurs intra- 
cellularly and produces heterococcoliths formed of radial arrays of complex crystal-units. In the haploid phase biomineralisation occurs extracellularly and produces holococcoliths formed of numerous minute euhedral crystallites. Evidence of this stems from culture observations of phase transitions (e.g. Parke and Adams 1960), observations of meiosis and syngamy (Gayral and Fresnel 1983), chromosome counts (Rayns 1962; Fresnel 1994), flow cytometry on cultured clones (Probert unpubl.), and observations of combination coccospheres from natural populations (for a review refer to Cros et al. 2000; Cros and Fortuño 2002; Geisen et al. 2002).

Thus the two phases potentially provide independent morphological evidence of differentiation. This potential has been realised in several cases, particularly through the recognition of rare combination coccospheres produced during phase transitions but also by the direct observation of phase changes in culture.

\section{Integrative interpretation}

Combining data from the sources mentioned above has allowed us to investigate fine-scale genotypic variation within the selected coccolithophores. Although we have not been able to gather evidence from all the various methods for all the species studied, there are strong patterns emerging, which allows for some generalization even if some information is missing. The different strands of evidence have produced significant evidence of different levels of genotypic variation within conventional species, which we will discuss in this review.

\section{Results}

In this section we present the data from each of the six CODENET species. Each case study was different but some strong patterns emerged. Although this is mainly a review, some previously unpublished data from our own observations are included as well. The sequence in which we present the various sources of data roughly represents the sequence in which the evidence became available and in some cases - as in Calcidiscus and Coccolithus - demonstrates how the introduction of further available data can radically change the interpretation.

\section{Umbilicosphaera sibogae and U. foliosa (Plate 1)}

Two varieties (U. sibogae var. sibogae and U. sibogae var. foliosa) have traditionally been recognised in this species based largely on coccosphere characters. There are correlative differences in coccolith morphology but it had been speculated that these were a consequence of the different coccosphere morphology. Hence alternative hypotheses were that these varieties were different life-cycle stages of a single species or discrete taxa. Umbilicosphaera was selected as a 
CODENET species to conduct a case study on infra-specific variation of two closely related taxa with an opportunity to study the evolutionary history as well. Based on molecular differences Sáez et al. (2003) have raised the two varieties to species rank, $U$. sibogae and $U$. foliosa, and this taxonomy is followed here.

\section{Quantitative and qualitative morphology}

The coccolithophorid genus Umbilicosphaera comprises four extant species (Winter and Siesser 1994) and two well-established extinct fossil species (Young 1998). The most common extant species $U$. sibogae and $U$. foliosa show a broad inter-oceanic occurrence and are common in the fossil record but there are few reliable data on their first occurrence. The genus Umbilicosphaera has a continuous and well-documented fossil record back to the Early Miocene (23 Ma) (Young 1998). Although McIntyre and Bé (1967) state that the two species can easily be distinguished on morphological grounds there has been some confusion in the taxonomy as Okada and McIntyre (1977) recombined Cycloplacolithus foliosus into $U$. sibogae var. foliosa on the basis that "extremely rare specimens having both types of coccoliths on a single coccosphere were observed". Curiously this taxonomic separation has been upheld by later researchers, even though research on Umbilicosphaera demonstrated a stable morphology under culture conditions and diagnostic cytological differences between the species (Inouye and Pienaar 1984). Our own research - with data from cultures, natural samples, and sediments - has now validated these findings and it seems likely that Okada and McIntyre (1977) distinguished the coccoliths of the two varieties using the expression of the suture lines, which is one of the least reliable criteria for species determination (see below and Young et al. this volume).

The two species exhibit significant diagnostic differences in both coccolith and coccosphere morphology. U. foliosa forms a compact spherical coccosphere consisting of up to 25 interlocking placoliths (Figs. 1,2) which are circular with a narrow central opening typically with a few hook-like spines protruding into the central opening (Figs. 2, 7). Both shields are bicyclic and convex distally, and the proximal shield is smaller than the distal shield (Figs. 8, 10). The proximal shield is composed of R-units and the distal shield of V-units. The inner half of the elements on the distal shield are imbricated dextrally and have straight sutures, the outer half kinked, with sinistral imbrication and serrated sutures (Figs. 7, 9). The central opening is spanned by an organic membrane (Figs. 1,8). The cells are not colonial and the protoplast fills the entire coccosphere (Fig. 5). Cells are nonmotile, but flagellar bases are present, uncalcified body scales are absent (Inouye and Pienaar 1984). Although intensive research has been conducted on cultures both within CODENET, and by other researchers (Inouye and Pienaar 1984), no phase changes have been observed and the life-cycle associations of the Umbilicosphaera spp. remain unknown.

In contrast, $U$. sibogae forms a large spherical to sub-spherical coccosphere consisting of 40 to more than 100 partly interlocking placoliths (Figs. 3, 4, 6). The placoliths are circular with a large central opening (Figs. 11, 13), the proximal shield is flat and typically larger than the convex distal shield (Fig. 12). Both 
shields are monocyclic, with the proximal shield composed of R-units and the distal shield of V-units. Elements on the distal shield are imbricated dextrally, sutures straight on the inner part of the rim, then kinked and incised laevogyre on the outer part of the rim (Fig. 11). An organic membrane spans the central opening (Fig. 12). The species is semicolonial, with each coccosphere typically containing $1-2$, occasionally four cells which do not fill the entire coccosphere (Fig. 6). Cells are non-motile, but flagellar bases are present (Probert unpubl.). As in U. foliosa, uncalcified body scales are absent (Probert unpubl.).

Working with sediment trap material, Baumann and Sprengel (2000) successfully used pore size and distal shield diameter to distinguish the two species and their data show little inter-annual size variation for $U$. sibogae coccoliths. In addition to this, own measurements of coccolith rim width and shield diameter reveal a distinct morphospace for the two taxa and no gradualistic morphological shift between them since their first occurrence in the fossil record.

\section{Culture studies and life-cycles}

Although intensive research has been conducted on cultures within CODENET, and also by other researchers (Inouye and Pienaar 1984) the life-cycle associations of the Umbilicosphaera spp. remain unknown. Culture studies in CODENET have, however, demonstrated the morphological stability of the two species in culture. Strains of both species have been maintained in culture for several years. During this period, the cultures were repeatedly checked by both light microscope (LM) and scanning electron microscope (SEM) but no evidence whatever of transitions between the two species was observed. A range of ecological conditions mainly light and temperature - was tested and no significant variation in coccolith size and characters was detected.

\section{Molecular studies}

Three genes were sequenced: $r b c \mathrm{~L}$ (Fujiwara et al. 2001), $18 \mathrm{~S}$ rDNA and tufA (Sáez et al. 2003). All of them show a high number of substitutions between the varieties. Based on the differences in morphology and the molecular differences Sáez et al. (2003) concluded that the two variants are indeed distinct biological species. Accordingly they suggest referring to them as separate species.

Estimates from a molecular clock (tufA tree) date the divergence of the lineage leading to the two species at 5.6 $( \pm 1.2)$ Ma (Sáez et al. 2003). Our own biostratigraphic work however dates the first occurrence of $U$. sibogae at $2.2 \mathrm{Ma}$ and that of $U$. foliosa at $2.9 \mathrm{Ma}$, so it can be hypothesised here that $U$. sibogae and U. foliosa are not direct sister taxa or differentiated morphologically much later than they did genetically.

\section{Status of taxa}

All the data indicate that $U$. sibogae and $U$. foliosa are discrete species. This includes morphometric evidence that the coccolith morphotypes do not intergrade 
and the recognition of additional species based on qualitative characters. Transitional morphotypes have not been observed in culture. Molecular data have revealed a significant number of substitutions between the species and point to a divergence time between 4.4 and 6.7 Ma. Nonetheless, the two taxa cluster together on all molecular trees so they are clearly closely related, as suggested by the coccolith morphology.

Plate 1 Umbilicosphaera spp.

Fig. 1: SEM of two U. foliosa coccospheres. U. foliosa cells are often found in clusters of up to four cells. Water sample, western Mediterranean, Alboran Sea, R/V Hesperides cruise MATER 2, station 69.

Fig. 2: SEM of two U. foliosa coccospheres. Note the presence of hook like protrusions in the central opening. Although this looks like a potential taxonomic character, cells with both types of coccoliths have frequently been observed. Water sample, N. Atlantic, R/V Meteor cruise 38-1, station 11.

Fig. 3, 4: SEMs of $U$. sibogae coccospheres. Note organic membrane in Fig. 4 spanning the central opening of some coccoliths. Water sample, S. Atlantic, off Namibia, R/V Meteor cruise M48-4, station 470 (Fig. 3) and station 20 (Fig. 4).

Fig. 5: Light micrograph of a cluster of four U. foliosa cells. Culture sample (ESP 6M1), western Mediterranean, Alboran Sea, R/V Hesperides cruise MATER 2.

Fig. 6: Light micrograph of a dividing $U$. sibogae cell. U. sibogae cells can be semicolonial with typically two cells in a single coccosphere. Note the large extracellular space. Culture material (ASM 39), western Mediterranean, Alboran Sea, R/V Hesperides cruise MATER 2.

Fig. 7: SEM of the bicyclic distal shield of an U. foliosa coccolith. Sediment trap sample, Indian Ocean, off Somalia.

Fig. 8: SEM of the bicyclic proximal shield of $U$. foliosa coccoliths. Note the organic membrane spanning the central opening. Culture sample (ESP 6M1), western Mediterranean, Alboran Sea, R/V Hesperides cruise MATER 2.

Fig. 9: SEM of the bicyclic distal shield of $U$. foliosa coccoliths. Note the straight suture lines of the inner cycle in contrast with the ragged suture lines of the outer cycle. Water sample, N. Atlantic, R/V Meteor cruise 38-1, station 13.

Fig. 10: SEM of an $U$. foliosa coccolith in lateral view. The distal shield is larger than the proximal shield. Water sample, western Pacific, Miyake-jima island, Ibo Port, Japan.

Fig. 11: SEM of the monocyclic distal shield of an U. sibogae coccolith. Proximal shield larger than distal shield. Water sample, western Mediterranean, Alboran Sea, R/V Hesperides cruise MATER 2, station 59.

Fig. 12: SEM of the monocyclic proximal shield of $U$. sibogae coccoliths. Note the organic membrane spanning the central opening. Water sample, western Mediterranean, Alboran Sea, R/V Hesperides cruise MATER 2, station 59.

Fig. 13: SEM of $U$. sibogae coccoliths from a single coccosphere. Note the size variation of the central opening and the rim. Water sample, western Mediterranean, Alboran Sea, R/V Hesperides cruise MATER 2, station 15.

Scale bars: Figs. 1-4: $5 \mu \mathrm{m}$, Figs. 5, 6: not to scale, Figs. 7, 8, 11-13: $2 \mu \mathrm{m}$, Figs. 9, 10: 1 $\mu \mathrm{m}$. 
Species level variation in coccolithophores 321

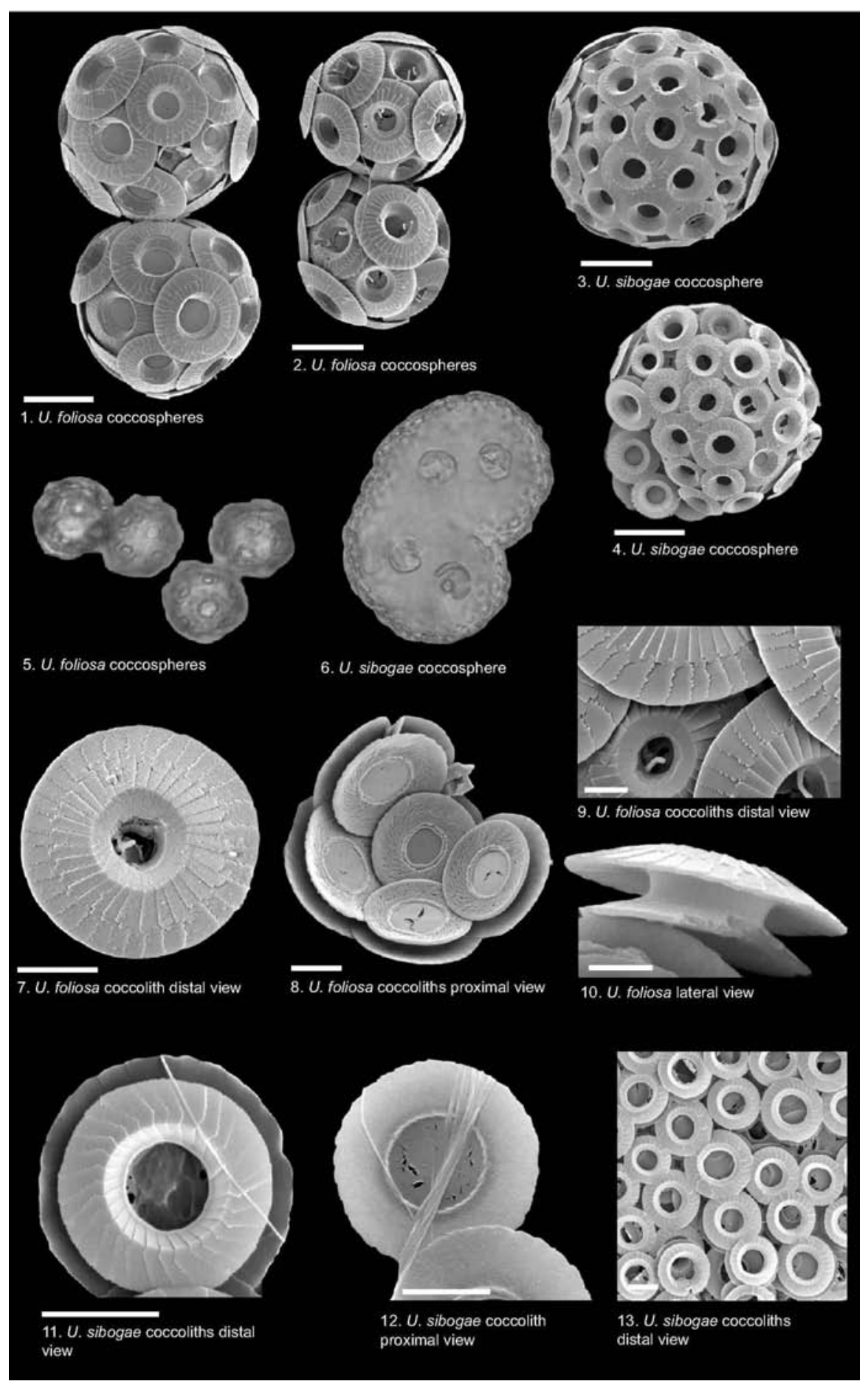




\section{Coccolithus spp. (Plate 2)}

Coccolithus pelagicus (Wallich 1877) is one of the most robust and longest ranging of extant coccolithophores and its life-cycle is exceptionally well documented (Parke and Adams 1960; Rowson et al. 1986; Geisen et al. 2002). It appeared in the early Palaeocene and it is common throughout the Cenozoic (Perch-Nielsen 1985), although this very long fossil record is based on a very broad species concept.

Today this species is commonly found in high latitudes, where it is known from the North Atlantic and the subarctic area (McIntyre and Bé 1967; Geitzenauer et al. 1977; Okada and McIntyre 1977; Samtleben and Schröder 1992). In addition, this genus is observed in low abundance in upwelling areas (e.g. Cachao and Moita 2000). Two morphotypes have been identified based on coccolith characters - a large, temperate form and a smaller, subarctic form. The morphotypes have generally been considered to represent ecophenotypic end-members of a single rather variable species. Recently however, based on life-cycle observations (Geisen et al. 2002) and genetic studies (Sáez et al. 2003), the species character of the putative ecophenotypes has been conclusively demonstrated and consequently named $C$. pelagicus (the subarctic species) and $C$. braarudii (the temperate species) and this taxonomy is followed here.

\section{Quantitative and qualitative morphology}

A range of studies with material from sediment trap, cultures and seawater samples have been carried out on the qualitative morphology of Coccolithus pelagicus sensu lato using both SEM and LM. Baumann et al. (2000) have used material from sediment traps from a north-south transect in the North Atlantic Ocean and demonstrated a clear change from a unimodal size distribution of the placoliths for the northern locations to a bi-modality in the more temperate locations. However, these data, based on coccolith rather than coccosphere measurements proved difficult to interpret due to the broad overlap in coccolith size between the two morphotypes. If measurements are performed on coccospheres, the two populations become clearly separable, with the temperate populations (C. braarudii) being dominated by large coccospheres (Fig. 1) and the subarctic populations $C$. pelagicus) by small coccospheres (Fig. 5). The two morphotypes share most of their qualitative characters. However, in the large form the central area is open and spanned by a cross-bar (Figs 2,3) whereas the central area is usually closed in the small form (Figs 6, 7). There is however evidence that these characters are secondary, size dependent characters since small specimens of the temperate form can have closed central areas and large specimens of the arctic form can have bars and open central areas.

Due to the nature of the morphological evidence there was a strong need to test whether the observed variations were ecophenotypic or genotypic in origin. Culture studies of both morphotypes under a range of different temperatures and light levels demonstrated morphological stability within each type, indicating that the 
differences in morphology (coccolith and coccosphere size and shape) are under genetic control.

\section{Life-cycles and holococcolith phase differentiation}

From a synthesis of observations on holococcolith morphology in cultures and plankton samples Geisen et al. (2002) demonstrated that the temperate and subarctic populations of Coccolithus produce different holococcoliths in the alternate life-cycle phase (Figs. 4, 8 respectively). Evidence here arises from both culture studies (Parke and Adams 1960; Rowson et al. 1986; Probert unpubl.) and life-cycle associations from combination coccospheres (Samtleben and Bickert 1990; Samtleben and Schröder 1992; Winter and Siesser 1994; Baumann et al. 1997). The holococcolith types have the same rim structure. The morphology of the central area, however, is different. In the holococcolithophore stage of the temperate Coccolithus, the central area consists of a central ellipse of crystallites with spokes radiating towards the rim (Fig. 4). The holococcolithophore stage of the subarctic Coccolithus however features coccoliths with the calcite rhombohedra arranged in parallel rows with each crystal lying on one face and partly touching adjacent faces (Fig. 8).

On the basis of life-cycle studies and morphological observations Geisen et al. (2002) amended the taxonomy and recombined Coccolithus to include two subspecies, C. pelagicus ssp. pelagicus and C. pelagicus ssp. braarudii.

\section{Ecological and biogeographical separation}

The two extant Coccolithus species show different, but partly overlapping biogeographies. C. pelagicus prefers colder, sub-arctic water masses with temperatures ranging from $-1{ }^{\circ} \mathrm{C}-14^{\circ} \mathrm{C}$ (Okada and McIntyre 1979; Winter et al. 1994) and C. braarudii prefers temperate waters and upwelling regimes (Baumann et al. 2000; Cachao and Moita 2000; Geisen et al. 2002) with optimal growth conditions in a temperature range between $13-18^{\circ} \mathrm{C}($ Cachao and Moita 2000). The discovery that extant Coccolithus consists of two species with significant differences in ecological preference and geographic distribution can shed a new light on the interpretation of results from the palaeobiogeography of Coccolithus spp. (Ziveri et al. this volume).

\section{Molecular studies}

Only one sub-arctic strain was available in culture so a multi-gene approach was used to compensate for the lack of strains. The two subspecies of Geisen et al. (2002) turned out to be identical on the conservative 18S rDNA gene. However, the faster evolving genes tufA and ITS rDNA showed variation between the two subspecies, whereas no net variation was observed among 8 strains of $C$. pelagicus ssp. braarudii (Sáez et al. 2003). Estimates from a molecular clock date the diver- 


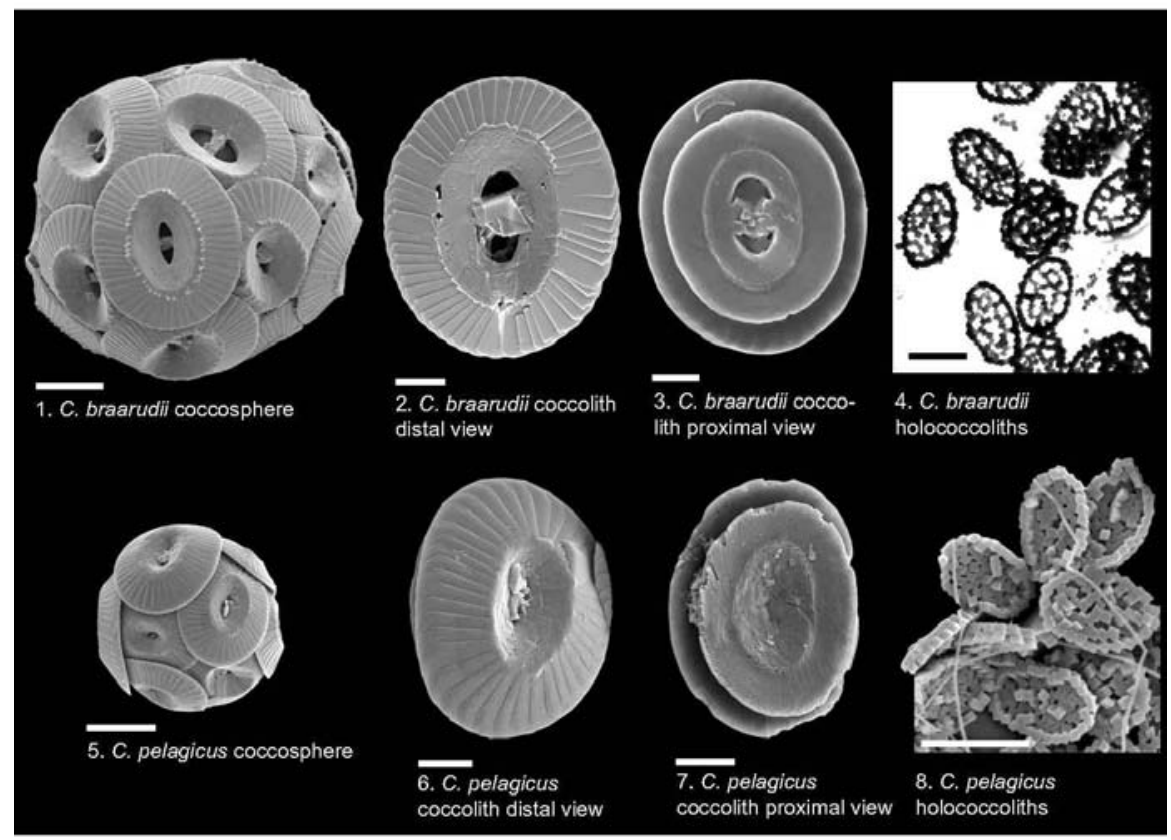

Plate 2 Coccolithus spp.

Fig. 1: SEM of a $C$. braarudii coccosphere. This species was previously known as the large, temperate morphotype of $C$. pelagicus. Water sample, S. Atlantic, off Namibia, R/V Meteor cruise M48-4, station 476.

Fig. 2: SEM of a C. braarudii coccolith in distal view. Culture sample (AS55T), western Mediterranean, Alboran Sea, R/V Hesperides cruise MATER 2.

Fig. 3: SEM of a C. braarudii coccolith in proximal view. Sediment trap sample, S. Atlantic. Image courtesy Babette Böckel, Univ. Bremen.

Fig. 4: Transmission electron micrograph of the holococcolithophore stage of C. braarudii. This stage was previously described as "Crystallolithus braarudii". Note the central ellipse of crystallites with radial spokes connected to the rim. Culture sample (LK1), SW France, off Arcachon.

Fig. 5: SEM of a $C$. pelagicus coccosphere. This species was previously known as the small, arctic morphotype of $C$. pelagicus. Water sample, N. Atlantic, off Iceland.

Fig. 6: SEM of a C. pelagicus coccolith in distal view. Culture sample (IBV 74), N. Atlantic, off Iceland.

Fig. 7: SEM of a C. pelagicus coccolith in proximal view. Water sample, N. Atlantic, off Iceland.

Fig. 8: SEM of the holococcolithophore stage of C. pelagicus. This stage was previously described as "Crystallolithus hyalinus". Note the central area with the crystallites arranged in parallel rows. Water sample, N. Atlantic, JGOFS cruise.

Scale bars: Figs. 1, 5: $5 \mu \mathrm{m}$, Figs. 2-4, 6-8: $2 \mu \mathrm{m}$. 
gence of the two taxa at $2.2( \pm 0.6) \mathrm{Ma}$ (Sáez et al. 2003). On the basis of these important molecular divergences between the two subspecies, Sáez et al. (2003) concluded that Geisen et al. (2002) were too conservative in assigning the intraspecific subspecies rank and raised the subspecies to species rank with the large, temperate species being $C$. braarudii and the small, subarctic species being C. pelagicus.

\section{Status of taxa}

It has been demonstrated that this taxon includes two discrete, arctic (Coccolithus pelagicus) and temperate (C. braarudi) species (Baumann et al. 2000; Sáez et al. 2003). These can be separated according to heterococcolith size, holococcolith morphology and temperature tolerance (Cachao and Moita 2000; Geisen et al. 2002). Molecular genetic data from a range of genes support this differentiation into two discrete, but closely related species. Results from a molecular clock indicate a divergence time of the sister taxa between 1.5 and $2.7 \mathrm{Ma}$ (Sáez et al. 2003).

\section{Helicosphaera spp. (Plate 3)}

The extant cosmopolitan genus Helicosphaera is usually regarded as consisting of two species (H. carteri and $H$. pavimentum) with three varieties in $H$. carteri (Jordan and Young 1990; Jordan and Green 1994; Jordan and Kleijne 1994). Helicosphaera is common in the sedimentary record and palaeontologists have successfully used fine morphovariants for biostratigraphy. More than 40 species are consequently recognised in the fossil record (Perch-Nielsen 1985). The most common extant form H. carteri var. carteri has a first occurrence of Late Oligocene age and $H$. carteri var. wallichii of Late Miocene (Tortonian) age (Young 1998).

The three varieties of $H$. carteri $-H$. carteri var. carteri, H. carteri var. wallichii and $H$. carteri var. hyalina - were described as separate species but were considered to differ only in central area pore development and so have been recombined as varieties (Jordan and Young 1990) and have been suggested to be intergradational morphotypes (Nishida 1979). Recent evidence from molecular studies (Sáez et al. 2003) has led to the conclusion that the variants $H$. carteri var. carteri and $H$. carteri var. hyalina are separate biological species, resulting in the species $H$. carteri and $H$. hyalina and this taxonomy is followed here. Based on life-cycle inferences and morphology we argue here that $H$. carteri var. wallichii should equally be restored to species rank.

\section{Quantitative and qualitative morphology}

Coccoliths of the genus Helicosphaera can be easily distinguished from other species due to their helical flange and their comparatively large size. Jafar and Martini (1975), Theodoridis (1984) have reviewed the genus Helicosphaera. The three extant varieties assigned to Helicosphaera share a number of morphological char- 
acters. All form ellipsoidal coccospheres with spirally arranged asymmetrical helicoliths. The cells are flagellate and the flagellar pole is surrounded by slightly modified coccoliths, which usually exhibit a larger wing (Figs. 1, 4, 7). Characters such as wing development and presence of tooth like protrusions on the wing are strongly variable within each variety and do not show obvious variation between the varieties. The central area characters, however, are distinctly different. In $H$. carteri the central area of the helicoliths show a bar, which separates two in-line openings (pores or slits) (Figs. 1-3). In contrast the central area of H. hyalina is characterised by the absence of pores or slits and shows larger blanket elements (Figs. 7-9). Finally, H. wallichii has a central area with a bar separating two dextrally aligned, oblique slits with kinked ends (Figs. 4-6). Measurements of coccolith size within Helicosphaera sensu lato, based on water column, sediment, and sediment-trap samples resulted in bi- or multimodal morphospace that were difficult to interpret and could either represent genotypic or ecophenotypic variation.

During CODENET multiple H. carteri (Fig. 1) cultures became available and the morphological stability of coccolith size and shape under a range of environmental conditions was demonstrated. Slit/pore size and shape were remarkably variable even within the same clonal culture, however, no specimens showed the oblique pores of $H$. wallichii. Rare coccoliths lacking pores did occur but these did not show the smaller size or large blanket elements characteristic of $H$. hyalina.

A single clone of $H$. hyalina (Fig. 7) was cultured and - in comparison with H. carteri - exhibited consistently smaller coccolith size in addition to the central area features described above. In addition the coccospheres are typically subspherical rather than ellipsoidal. These features remained stable in culture and proved valuable for species recognition.

We did not successfully isolate $H$. wallichii, but re-examination of a coccolith sample provided previously by I. Inouye from a Helicosphaera culture isolated off Japan showed that this was a strain of $H$. wallichii, with all coccoliths showing oblique slits in the central area (Fig. 4). We note that his strain was used by Fujiwara et al. (2001) in their analysis of haptophyte phylogeny using rbcL, and named there as $H$. carteri.

A review of our large collection of scanning electron micrographs of coccoliths and coccospheres of Helicosphaera from all oceans revealed that on coccospheres of $H$. wallichii and $H$. hyalina all visible coccoliths showed the typical features of the species. By contrast a rather high morphological variability of the central area characters is often seen on H. carteri coccospheres, as shown by (Nishida 1979). Pore size is very variable, the two pores may merge into a single slit, and occasionally one or even both pores are absent. $H$. carteri coccoliths without pores are nonetheless readily separable from $H$. hyalina coccoliths by their larger size and smaller blanket elements. The findings on the natural samples hence support our morphological observations on the cultured clones. These results from morphological work indicate that there is a strong genotypic control on the morphological variation in Helicosphaera. 


\section{Life-cycles and holococcolith phase differentiation}

Recent evidence from combination coccospheres of $H$. carteri with a holococcolithophore "Syracolithus catilliferus" (Figs. 10-12) (Cros et al. 2000) and combination coccospheres of the holococcolithophores "Syracolithus catilliferus" and "Syracolithus confusus" (Fig. 13) (Geisen et al. 2002) suggests that both holococcolithophores can occur on the haploid phase of the life-cycle of H. carteri. Cros et al. (2000) and Geisen et al. (2002) note the close morphological relationship between the two holococcoliths involved (Figs 10,12) and explain this similarity by non-genotypic variations in the degree of calcification. Although the available examples are few and based on observations on natural populations only, they provide convincing evidence to treat both holococcolithophores as junior (heterotypic) synonyms of $H$. carteri.

We have further tentative evidence from a single possible combination coccosphere for a life-cycle association of $H$. wallichii with a holococcolithophore Syracolithus dalmaticus (Figs. 14-16). This is not a particularly clear example of a combination cell and could indeed be an accidental association. However, in our field samples of the variant wallichii the holococcolithophore $S$. dalmaticus usually occurs as well. In particular we found several specimens of both $H$. wallichii and $S$. dalmaticus in samples collected from around the island Miyake-jima, Japan in 2001. This is the location from which I. Inouye's culture of $H$. wallichii was previously isolated. So we tentatively conclude that there is evidence for differentiation of both holococcolith and heterococcolith between $H$. wallichii and H. carteri.

NB Helicosphaera wallichii (Lohmann 1902) Boudreaux and Hay (1969) has priority over Syracolithus dalmaticus (Kamptner 1927) Loeblich and Tappan (1966), hence - if the combination is proved - the correct name for the species will be $H$. wallichii. There is no evidence available on the haploid phase of H. hyalina, although it is interesting to note that the holococcoliths within the genus Helicosphaera have a highly distinctive ultrastructure, formed predominantly of aligned rhombohedral crystallites (Fig. 11). One further holococcolithophore, S. ponticuliferus, is known to have this ultrastructure and so is a prime candidate for a possible $H$. hyalina holococcolithophore.

\section{Molecular studies}

Two genes - the conservative 18S rDNA and the faster evolving tufA - were targeted for the two varieties carteri and hyalina within Helicosphaera available in culture. However, despite numerous attempts with $H$. hyalina, it was only possible to sequence $18 \mathrm{~S}$ rDNA for $H$. carteri. The tufA gene was successfully sequenced from both taxa and exhibited a large number of substitutions between them. A molecular clock analysis of this variation allowed inference of a most recent common ancestor for these two taxa at $10.2 \pm 2 \mathrm{Ma}$ (Sáez et al. 2003). Based on the differences in morphology and the molecular data Sáez et al. (2003) recommended that the varieties should be restored to species rank, and so named $H$. carteri and $H$. hyalina. Due to the lack of new isolates of $H$. wallichii comparative molecular data are not available for it. 
Plate 3 Helicosphaera spp.

Fig. 1: SEM of an H. carteri coccosphere. The helicoliths show the typical spiral arrangement and the circumflagellar coccoliths possess enlarged flanges. The central area of this specimen shows the typical morphology with two aligned slits separated by a bar. Morphotypes with small round pores and intermediate central area morphologies have also been observed. Note the small triangular protrusions on the flange. Water sample, N. Atlantic, Portuguese shelf, R/V Andromeda cruise CODENET 2, station 6.

Fig. 2: SEM of a $H$. carteri coccolith in proximal view. Sediment trap sample, S. Atlantic. Image courtesy Babette Böckel, Univ. Bremen.

Fig. 3: SEM of a $H$. carteri coccolith in distal view. Sediment trap sample, S. Atlantic. Image courtesy Babette Böckel, Univ. Bremen.

Fig. 4: SEM of a $H$. wallichii coccosphere. The central area shows the typical morphology with two angled slits with kinked ends, separated by a bar. This fine morphological feature is stable in culture. Note the small triangular protrusions on the flange. Water sample, western Pacific, Miyake-jima island, Miike Port, Japan.

Fig. 5: SEM of a $H$. wallichii coccolith in proximal view. Note the kinked ends of the aligned slits. Water sample, western Pacific, Miyake-jima island, Miike Port, Japan.

Fig. 6: SEM of a $H$. wallichii coccolith in distal view. Sediment trap sample, Indian Ocean, off Somalia.

Fig. 7: SEM of a $H$. hyalina coccosphere. The central area is filled with tangentially arranged needle shaped elements. Note the small triangular protrusions on the flange. Culture sample (NAP 11), Mediterranean, off Naples, Italy.

Fig. 8, 9: SEM of a H. hyalina coccolith in proximal view (Fig. 8) and distal view (Fig. 9). Culture sample (NAP 11), Mediterranean, off Naples, Italy.

Fig. 10: SEM of a H. carteri coccosphere in the holococcolith bearing stage. This stage was previously described as "Syracolithus catilliferus" and is referred to as H. carteri HO solidtype. Water sample, N. Atlantic, off Canary Islands, R/V Poseidon cruise P233B, station 3.

Fig. 11: SEM of $H$. carteri coccoliths in the holococcolith stage. Water sample, Antarctic Ocean, cruise JR 48.

Fig. 12: SEM of a H. carteri coccosphere in the holococcolith bearing stage. This stage was previously described as "Syracolithus confusus" and is referred to as H. carteri HO perforate-type. Water sample, western Mediterranean, off Barcelona.

Fig. 13: SEM of a $H$. carteri coccosphere in the holococcolith bearing stage. Note that presence of coccoliths of both $H$. carteri $\mathrm{HO}$ solid and perforate. This is seen as an example of intraspecific variation in the degree of calcification. Water sample, NW Mediterranean, cruise MESO-96, station F2.

Fig. 14: SEM of a S. dalmaticus holococcolithophore. Water sample, western Pacific, Miyake-jima island, Ibo Port, Japan.

Fig. 15: SEM of a detail of $S$. dalmaticus holococcoliths. Water sample, western Mediterranean, Alboran Sea, R/V Hesperides cruise MATER 2, station 69.

Fig. 16: SEM of a tentative $H$. wallichii $-S$. dalmaticus combination coccosphere. Water sample, Gulf of Mexico, R/V Gyre cruise 92-G-03, station 9.

Scale bars: Figs. 1, 4, 7, 10, 12-14: $5 \mu \mathrm{m}$, Figs. 2, 3, 5, 6, 8, 9, 11, 15: $2 \mu \mathrm{m}$. 
Species level variation in coccolithophores 329

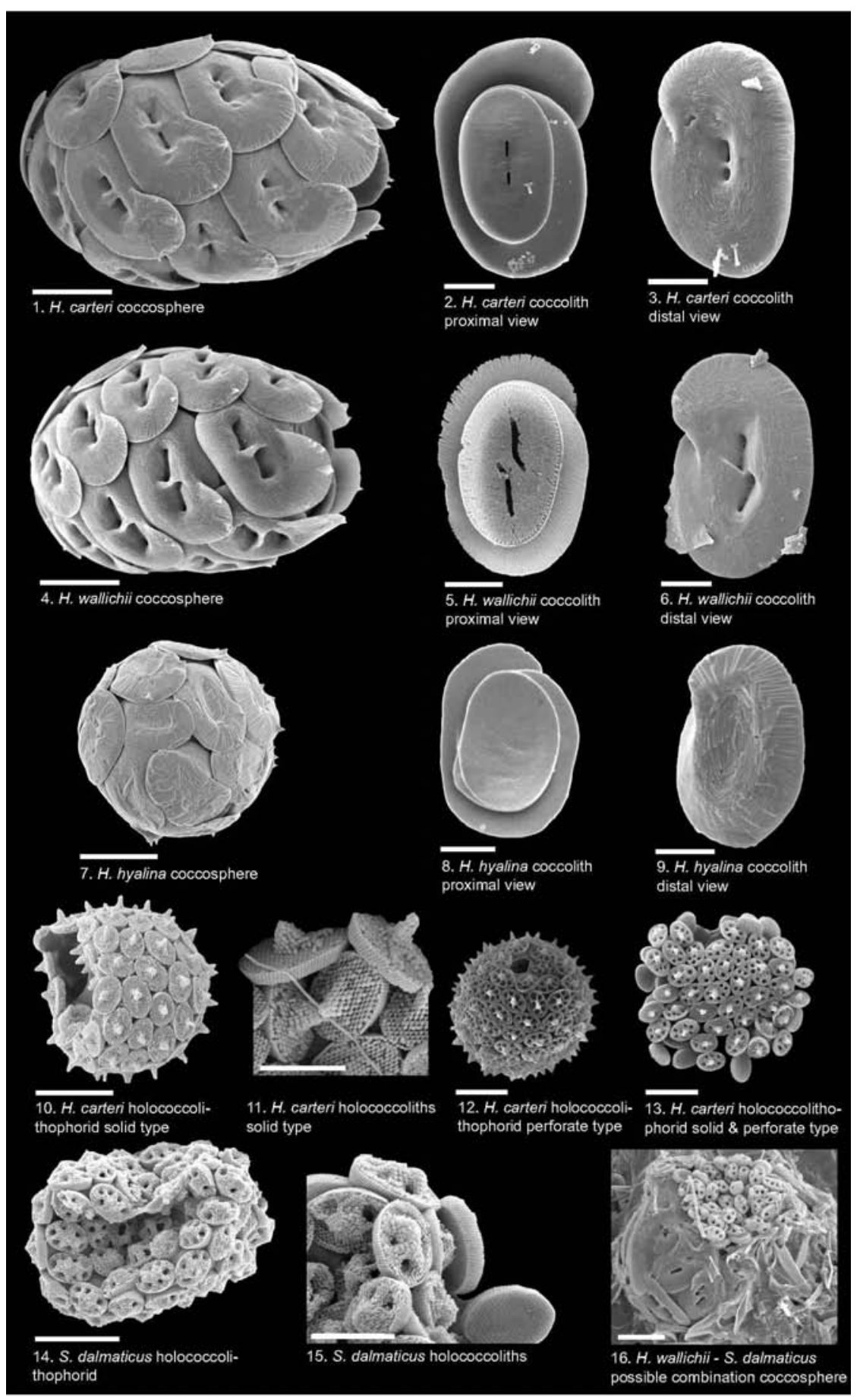




\section{Status of taxa}

Morphometric analyses again produced ambiguous patterns, which were difficult to interpret. Our key result came from culture isolation of a disputed morphovariant $-H$. hyalina. Contrary to expectations the coccolith morphology has proved stable in culture indicating again that a subtle morphological variant is under genotypic control. On the basis of our new results from morphological and molecular studies Sáez et al. (2003) have concluded that the two varieties are in fact separate, albeit closely related species and that their most recent common ancestor would have lived between 8.2 and 12.2 Ma. Although molecular data are still pending, evidence from the morphology, life-cycle data and previous culture observations strongly support that the previously described variant $H$. carteri var. wallichii should be considered a discrete species as well. These findings have led to the suggestion that in this species sympatric evolution of a phenotypically plastic population might lead to gradualistic change in the range of morphological variation within a single species.

\section{Calcidiscus spp. (Plate 4)}

Together with the Gephyrocapsa-Emiliania plexus, Calcidiscus is probably the best documented coccolithophorid genus (Brand 1981; Knappertsbusch et al. 1997, Knappertsbusch 2000; Baumann and Sprengel 2000; Renaud and Klaas 2001; Renaud et al. 2002; Quinn et al., 2003). Like the aforementioned genera it has a broad, inter-oceanic occurrence spanning a range of ecological variation and a very good, continuous fossil record through the last $23 \mathrm{Ma}$. Three extant morphotypes have been tentatively identified, based largely on size of the coccoliths and coccospheres and there has been much speculation as to whether this variation represents distinct species or ecophenotypes. Recently, however, Geisen et al. (2002) and Sáez et al. (2003) have conclusively demonstrated that the large and intermediate morphotypes do represent distinct biological species $-C$. quadriperforatus and C. leptoporus respectively - and this taxonomy is followed here. A detailed review of this species complex is presented by Quinn et al. (this volume) and for reasons of completeness we summarise the available data here.

\section{Quantitative and qualitative morphology}

Three morphotypes (large, intermediate and small) were identified within extant populations of Calcidiscus, based on the size of coccoliths and coccospheres (for references see Quinn et al. this volume) (Figs. 1-3). The morphospace based on coccolith size measurements and element counts reveals a trimodal distribution, albeit with broadly overlapping margins and the modes compare well with the size range reported for Holocene material. It has, however, been pointed out that size measurements as a sole character are not sufficient to distinguish the morphotypes. If other, qualitative characters are added, the morphotypes become easily separable (Kleijne 1993; Baumann and Sprengel 2000; Geisen et al. 2002) (Figs. 4-9). 
Research during CODENET has additionally shown that at least two of the morphotypes exhibit a stable morphology in culture under varying environmental conditions (Quinn et al. 2003; Quinn et al. this volume).

\section{Life-cycles and holococcolith phase differentiation}

Observations on plankton samples and on cultured clones of Calcidiscus have demonstrated that the large and intermediate morphotype independently form lifecycle associations with distinctly different holococcolithophores (Figs. 10-12). In combination with the morphological observations this led Geisen et al. (2002) to amend the taxonomy, assigning subspecies rank to the morphotypes.

\section{Molecular studies}

The two subspecies identified by Geisen et al. (2002) can be distinguished using both the conservative $18 \mathrm{~S}$ rDNA and the faster evolving tufA genes. With this information Sáez et al. (2003) concluded that Geisen et al. (2002) were too conservative in using the intra-specific rank subspecies and have therefore raised the subspecies to species level. Furthermore they present evidence for two distinct genotypes within $C$. quadriperforatus and assume that this represents a case of recent cryptic speciation. In the same study they calculate the divergence time for C. leptoporus (the intermediate "morphotype") and C. quadriperforatus (the large "morphotype") at 11.6 $\pm 1.6 \mathrm{Ma}$, which correlates well with the results of Knappertsbusch (2000) from the morphological classification of Calcidiscus in the fossil record.

\section{Status of taxa}

Initial results from oceanographic and culture studies produced conflicting data. However, subsequent data from holococcolith morphology (Geisen et al. 2002) and a combined morphological and molecular genetic study of a large collection of culture isolates proved that the variation was predominantly genotypic (Sáez et al. 2003). This has provided further insights with respect to the occurrence and ecological preferences of the former morphotypes (Baumann and Sprengel 2000; Renaud and Klaas 2001; Renaud et al. 2003). The molecular clock and findings from the fossil record point to a relatively deep divergence of the Calcidiscus species. An additional surprising result from the molecular studies was the discovery of recent cryptic speciation within C. quadriperforatus.

\section{Gephyrocapsa oceanica and related species (Plate 5)}

The genus Gephyrocapsa constitutes a late Neogene group of heterococcolithophores that first developed in the late Pliocene, about 3.5 Ma ago (Reticulofenestra 
Plate 4 Calcidiscus spp.

Fig. 1: SEM of a C. quadriperforatus coccosphere. This species was previously known as the large morphotype of $C$. leptoporus. Water sample, western Pacific, Miyake-jima island, Miike Port, Japan.

Fig. 2: SEM of a C. leptoporus coccosphere. This species was previously known as the intermediate morphotype of C. leptoporus. Culture sample (NS 10-2), S. Atlantic, off South Africa, R/V Agulhas cruise MARE 2.

Fig. 3: SEM of a Calcidiscus sp. SMALL coccosphere. Note the kinked suture lines that can be traced into the central pore. This species was previously known as the small morphotype of $C$. leptoporus. As no holococcolithophore stage has been identified an informal classification is used. Water sample, S. Atlantic, off Namibia, R/V Meteor cruise M48-4, station 472.

Fig. 4: SEM of a C. quadriperforatus coccolith in distal view. Note the curved suture lines and the obscured zone around the central pore. Culture sample (ASM 27), western Mediterranean, Alboran Sea, R/V Hesperides cruise MATER 2.

Fig. 5: SEM of $C$. leptoporus coccoliths in distal view. Note the curved suture lines that can be traced into the central pore. Water sample, western Pacific, Miyake-jima island, Chyotarou Port, Japan.

Fig. 6: SEM of Calcidiscus sp. SMALL coccolith in distal view. Note the kinked and ragged appearance of the suture lines that can be traced into the central pore. Water sample, western Pacific, Miyake-jima island, Chyotarou Port, Japan.

Fig. 7: SEM of a C. quadriperforatus coccolith in proximal view. Water sample, western Pacific, Miyake-jima island, Ibo Port, Japan.

Fig. 8: SEM of C. leptoporus coccoliths in proximal view. Water sample, western Pacific, Miyake-jima island, Chyotarou Port, Japan.

Fig. 9: SEM of Calcidiscus sp. SMALL coccoliths in proximal view. Water sample, N. Atlantic, R/V Meteor cruise 38-1, station 12.

Fig. 10: SEM of the holococcolithophore stage of C. quadriperforatus. This stage was previously described as "Syracolithus quadriperforatus". Water sample, N. Atlantic, off the Canary Islands, R/V Poseidon cruise P233B, station 2.

Fig. 11: SEM of the holococcolithophore stage of C. leptoporus. This stage was previously described as "Crystallolithus rigidus". Culture sample (NS 10-2), S. Atlantic, off South Africa, R/V Agulhas cruise MARE 2.

Fig. 12: Detail of a SEM of a combination coccosphere bearing coccoliths of both the holococcolithophore stage of $C$. quadriperforatus and the associated holococcolithophore stage. Water sample, western Mediterranean, Alboran Sea, R/V Hesperides cruise MATER 2, station 69.

Scale bars: Figs. 1-3, 10: $5 \mu \mathrm{m}$, Figs. 4-9, 12: $2 \mu \mathrm{m}$, Fig. 11: $1 \mu \mathrm{m}$. 
Species level variation in coccolithophores 333

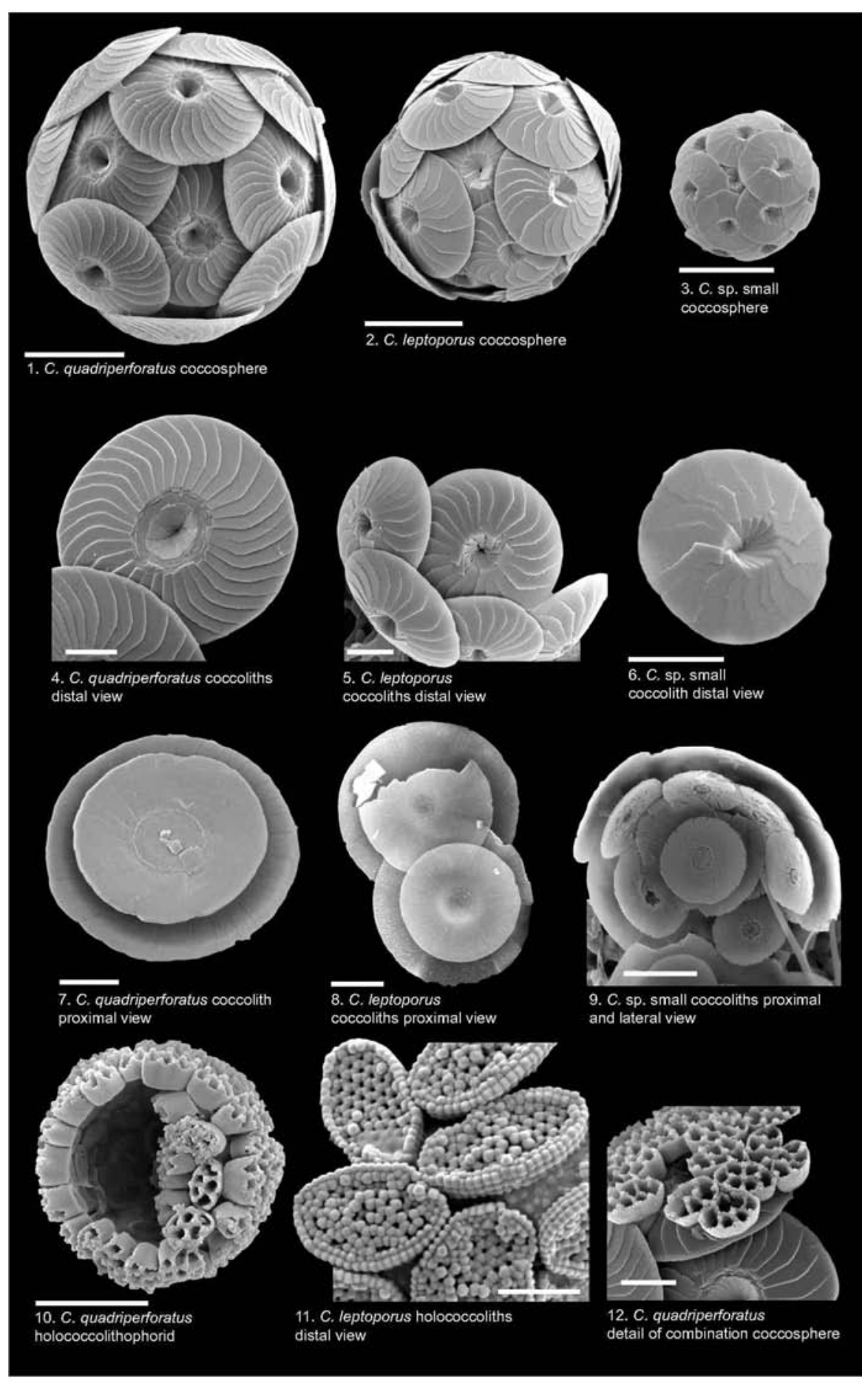


pseudoumbilicus Zone, NN 15), became dominant in the Early Pleistocene, and has yielded ecological dominance during the last $85 \mathrm{kyr}$ to the descendant species Emiliania huxleyi. Because of the close relationship of $E$. huxleyi with genus Gephyrocapsa, E. huxleyi has been regarded as a modern ecological surrogate for the small gephyrocapsids of the Pleistocene, which it has replaced in the modern phytoplankton (e.g. Gartner 1988). Phylogenetically E. huxleyi is part of the Gephyrocapsa clade and hence needs to be considered within the group.

Gephyrocapsa is a complex genus, which shows considerable morphological variability and has been intensively studied by palaeontologists in order to produce a high-resolution biostratigraphic subdivision of the Quaternary. Thus, there are many extant and extinct species classified under the genus Gephyrocapsa, and most of which are defined solely by morphologic characters (e.g. Pujos 1985). According to this taxonomy the modern Gephyrocapsa assemblage consists of four species with first appearances between 1-3.5 Ma (Samtleben 1980; Matsuoka and Okada 1990; Young 1991). However, detailed morphometry, qualitative morphological, and biogeographical work indicates that each of these species consists of different morphotypes (Bollmann 1997; Bollmann et al. 1998; Hagino and Okada 2001; Cros 2002). Emiliania huxleyi is the most abundant living coccolithophore and appears to have extremely broad ecological affinities, occurring in all of the main oceanic conditions. Large-scale blooms which mainly consist of $E$. huxleyi, are regularly observed during early summer in the northern North Atlantic (e.g. Brown and Yoder 1993; Holligan et al. 1993). This species is easy to maintain in culture and has been subject to intensive studies, combining observations from culture and oceanic populations (e.g. Westbroek et al. 1989; Young and Westbroek 1991; Westbroek et al. 1993; Westbroek et al. 1994; Young 1994). In addition, Emiliania huxleyi has a very well constrained first occurrence at only $270 \mathrm{ka}$ (Thierstein et al. 1977).

\section{Quantitative and qualitative morphology}

The genus Gephyrocapsa was first described by Kamptner (1943) and included only one species, G. oceanica, which he later divided into two varieties, G. oceanica var. typica and G. oceanica var. californiensis (Kamptner 1956). Much later, the first small Gephyrocapsa species, G. aperta, was described (Kamptner 1963). Since then more than 20 species have been described within this genus on the basis of various criteria. Many of these species have been distinguished using morphologic criteria detectable with LM such as size, proportion of the central area and bridge angle (e.g. Boudreaux and Hay 1969; Hay and Beaudry 1973). Some have been cited only once, whereas others, such as Gephyrocapsa reticulata (Nishida 1971), lack a crossbar and, therefore, cannot be assigned to the genus Gephyrocapsa. Whereas large species like G. oceanica (Figs. 1,2) and G. muellerae (Figs. 5,6) are relatively easy to distinguish even with light microscopy it was only after the SEM replaced LM and transmission electron microscopes that some characteristic small species such as G. ornata (Figs. 3, 4), G. ericsonii (Figs. $7,8)$ or G. aperta were accurately defined. A major step forward in the classification of Gephyrocapsa species came when Bréhéret (1978) and Samtleben (1980) 
independently demonstrated the feasibility of distinguishing different morphological species by using simple quantifiable morphometrical characters (mainly coccolith size and bridge angle). Comparable size criteria were applied to the entire Gephyrocapsa complex when Matsuoka and Okada $(1989,1990)$ investigated time-progressive variations in the morphology of the genus.

All extant species of the genus Gephyrocapsa build spherical to sub-spherical coccospheres of oval placoliths with a diagonal bridge crossing the central area (Figs. 1-8). This distinctive feature makes even the smallest specimens identifiable at generic level. Many variations of the coccolith bridge exist. Some have a high-arched bridge, whereas others have a low-profile bridge formed by fine rodlike elements.

Recently, morphological analysis of Holocene Gephyrocapsa assemblages revealed six dominant morphological associations (Bollmann 1997), which the author described informally, since he reserved judgment on whether these corresponded to discrete species or, in part, to ecophenotypes. The different morphotypes appear to have distinct environmental preferences with respect to temperature and productivity but do not show intermediate morphologies in intermediate ecological conditions. During CODENET only G. oceanica was successfully isolated and so available for study in detail in culture (C. Klaas unpubl. data). Data emerging from this work demonstrate a strong stability of morphological characters within the species.

Emiliania huxleyi (Lohmann 1902), Hay and Mohler, 1967 in Hay et al. 1967 forms spherical coccospheres consisting of fewer than 10 to up to more than 50 partially interlocking placoliths (Figs. 9-12). These oval placoliths typically are formed of T-shaped elements and have an elliptical central area. Young and Westbroek (1991) distinguished four varieties of E. huxleyi - types A (Figs. 9, 12), B, C (Fig. 11), and var. corona (Fig. 10) based on culture observations, immunochemical tests and plankton observations, although they stated that biometrical analyses do not separate these types easily. E. huxleyi was not a target of CODENET research but our limited culture observations have supported the pattern of stable genotypically determined morphology in culture.

\section{Molecular studies}

E. huxleyi has previously been genetically characterised in a number of studies. Medlin et al. (1996) sequenced a number of clonal strains from all oceans which were identical with regard to the chloroplastic16S and the nuclear $18 \mathrm{~S}$ rDNA and the spacer region between the Rubisco rbcL and rbcS. However, genetic fingerprinting techniques such as RAPDs (random amplification of polymorphic DNA) and AFLPs (amplified fragment-length polymorphism) revealed significant genetic differences between strains (for a review refer to Mueller and LaReesa Wolfenbarger 1999). Using RAPD Medlin et al. (1996) found that all strains except for one pair were genetically distinct and that this genetic diversity is reflected in the morphology and the ecological distribution of the strains. On the basis of the RAPD study by Medlin et al. (1996) the proposed variants by Young and Westbroek (1991) were formally emended. 


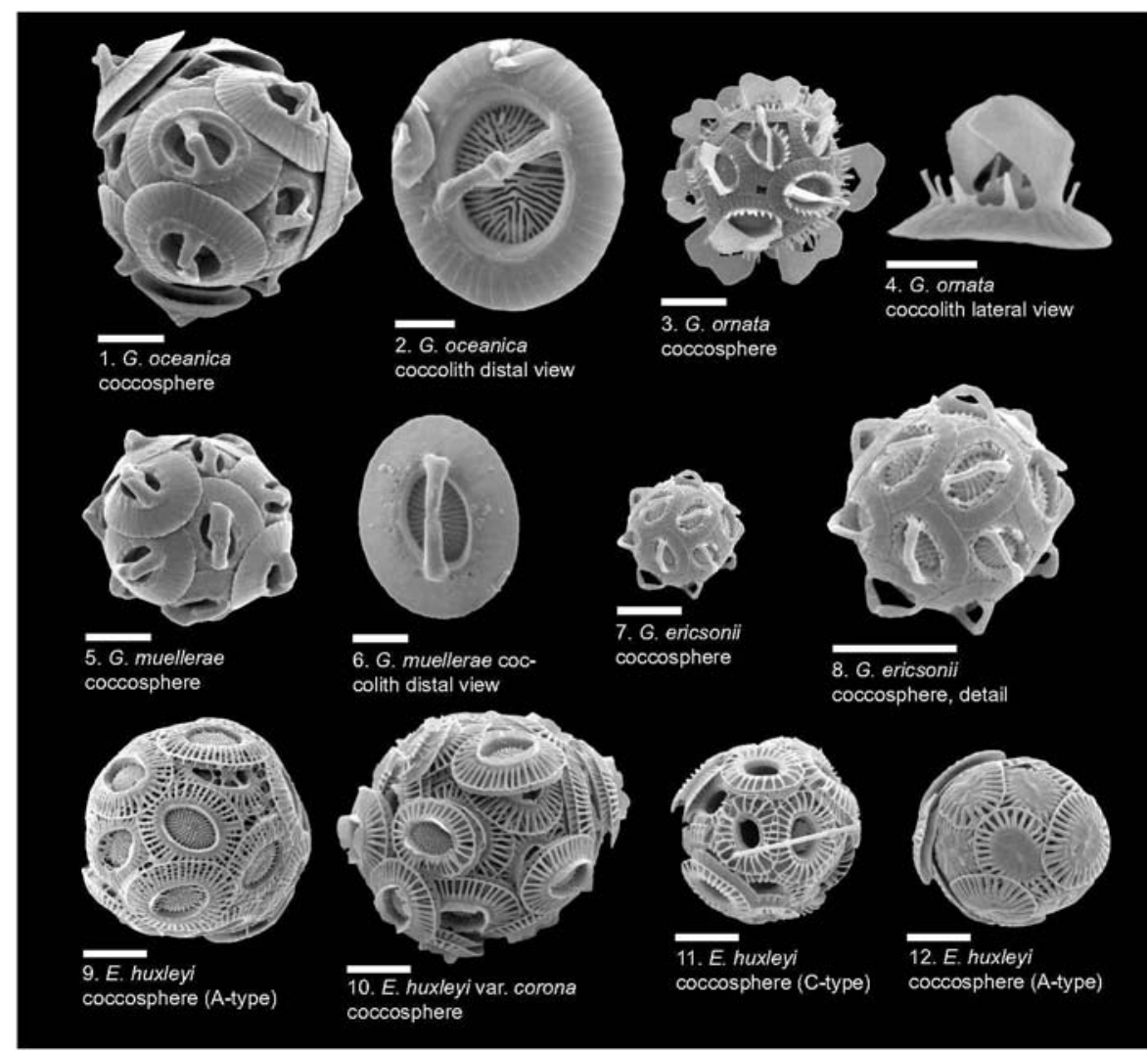

Plate 5 Gephyrocapsa spp. and Emiliania spp.

Fig. 1: SEM of a G. oceanica coccosphere. Water sample, western Mediterranean, Alboran Sea, R/V Hesperides cruise MATER 2, station 59.

Fig. 2: SEM of a G. oceanica coccolith in proximal view. Sediment trap sample, S. Atlantic. Image courtesy Babette Böckel, Univ. Bremen.

Fig. 3: SEM of a G. ornata coccosphere. Water sample, western Mediterranean, Alboran Sea, R/V Hesperides cruise MATER 2, station 44.

Fig. 4: SEM of a G. ornata coccolith in lateral view. Water sample, western Mediterranean, Alboran Sea, R/V Hesperides cruise MATER 2, station 69.

Fig. 5: SEM of a G. muellerae coccosphere. Water sample, western Mediterranean, Alboran Sea, R/V Hesperides cruise MATER 2, station 69.

Fig. 6: SEM of a G. muellerae coccoliths. Sediment trap sample, N. Atlantic, JGOFS cruise.

Fig. 7, 8: SEM of a G. ericsonii coccosphere. Fig. 16 displays an enlarged view of the same specimen. Water sample, western Mediterranean, Alboran Sea, R/V Hesperides cruise MATER 2, station 15.

Fig. 9: SEM of a E. huxleyi coccosphere. The coccoliths exhibit the A-type morphology. Water sample, N. Atlantic, R/V Meteor cruise 42-4B, station US 1B. 
Plate 5 (cont.)

Fig. 10: SEM of a E. huxleyi var. corona coccosphere. Note the collar surrounding the central area. Water sample, N. Atlantic, off Canary Islands, R/V Poseidon cruise P233B, station 3 .

Fig. 11: SEM of a E. huxleyi coccosphere. The coccoliths exhibit the C-type morphology. Water sample, N. Atlantic, R/V Meteor cruise 38-1, station 12.

Fig. 12: SEM of an E. huxleyi coccosphere. The coccoliths exhibit the A-type morphology with the central area being overcalcified. Water sample, western Mediterranean, Alboran Sea, R/V Hesperides cruise MATER 2, station 64.

Scale bars: Figs. 1, 3, 5, 7-12: $2 \mu \mathrm{m}$, Figs. 2, 4, 6: $1 \mu \mathrm{m}$.

Recently Iglesias-Rodríguez et al. (2002a, 2002b) further demonstrated a high degree of polymorphism in isolates of $E$. huxleyi of different geographical origin using AFLP and microsatellite loci. Gene flow and calculations of genetic diversity using population statistics are presently under way. All of these studies predict that $E$. huxleyi must be undergoing frequent sexual recombination to maintain such high diversity among populations reproducing vegetatively to maintain high biomass.

In CODENET a number of E. huxleyi and G. oceanica strains and Emiliania huxleyi morphotype $\mathrm{R}$ were sequenced (Sáez et al. unpublished). With the slowly evolving $18 \mathrm{~S}$ rDNA all the sequences obtained are identical, which is consistent with a recent divergence of these genotypes. But isolates, either from the same morphological species or not, appear genetically distinct at the fast evolving tufA gene. Unlike $C$. pelagicus or $C$. leptoporus, where each morphotype was monophyletic, E. huxleyi and G. oceanica species and morphotypes were mixed in relation to the tufA genotypes. These unexpected findings have been interpreted to be the result of ancient (or shared) polymorphisms at the tufA gene, which have persisted through the speciation events in these different lineages. Thus future work regarding the genetic variability of he species in correlation to their ecological preferences remains an interesting topic and is likely to be solved using DNA fingerprinting methods, such as microsatellites or SNPs (single nucleotide polymophism) analyses. Due to the failure to isolate other Gephyrocapsa and Emiliania species, information about their genetic variability is still lacking.

\section{Life-cycles and holococcolith phase differentiation}

The life-cycle of E. huxleyi consists of coccolith bearing non-motile, diploid $\mathrm{C}$ cells and motile, haploid, scale-bearing $\mathrm{S}$ cells (see Billard and Inouye this volume). Holococcoliths are not produced in the haploid stage. A third type of cells the naked $\mathrm{N}$ cells - is diploid and does not appear to be part of the haplo-diplontic life-cycle, but a mutant. All cell types are capable of indefinite asexual reproduction by binary fission. Few life-cycle observations are available for Gephyrocapsa spp. But, as in Emiliania spp., the haploid stage is motile and covered with unmineralised scales (Probert unpubl. data). It is possible that the scales from S-cells of Emiliania and Gephyrocapsa may provide morphological criteria to help assess fine-scale speciation patterns but such data is not yet available. 


\section{Ecological and biogeographical separation}

By measuring the reproduction rates of a large number of E. huxleyi and G. oceanica clones under the same environmental conditions, Brand $(1981,1982)$ demonstrated both the stability of this parameter in single clones, and considerable variation between clones. He therefore concluded that a natural population is not clonal but consists of a mixture of genotypes with different reproductive potentials (Brand 1982). However he did not claim that this differentiation could only be due to the existance of reproductive barriers: "these species (...) either undergo extensive genetic recombination with the resulting genotypes having different reproductive potentials or exist as complexes of coexisting clonal lines" (Brand 1982). Paasche (2002) points out the relative tolerance of coastal clones of E. huxleyi to salinity variations, contrasted by less tolerant oceanic E. huxleyi clones. Young and Westbroek (1991) describe E. huxleyi type A, B and C as well as the variant corona but they reserve judgement whether these are typical of distinct environments. Emiliania appears to have diverged into at least five discrete sub-species with partially overlapping biogeographies (Young and Westbroek 1991; Medlin et al. 1996; Findlay and Giraudeau 2001).

In the genus Gephyrocapsa culture studies were limited because most of the recognized species were not isolated into culture. However, the hypothesis of differential ecologies of the species has been tested in detail through derivation of a temperature transfer function based on the distribution of Gephyrocapsa species (Bollmann et al. 2002).

\section{Status of taxa}

In the case of E. huxleyi there is evidence of different levels of genotypic variation. Firstly, there is the well-documented appearance of genus Emiliania at about $270 \mathrm{ka}$, which has since diverged into a number of well-defined species, detectable by molecular and morphological methods. Secondly, there is evidence of a high genotypic variability at the population scale. It has been demonstrated that a population is not a single clone or genotype, but a mixture of genetically distinct clones, which are attuned to yield maximum growth rates in a range of environmental conditions. Recent molecular studies using microsatellite loci have confirmed that populations of E. huxleyi - separated by major oceanic boundaries show a distinct genetical fingerprint and can thus be spatially separated.

The overall pattern of variation in Gephyrocapsa is comparable with Emiliania. A relatively young genus has diverged into a number of well-defined morphological species (G. muellerae, G. ericsonii, G. oceanica, G. ornata) most of which comprise two or more morphotypes (Bollmann 1997) which probably do represent pseudo-cryptic species. In addition, different clones of $G$. oceanica have been tested for their environmental preferences and they reveal a genotypic variability of the same nature as in Emiliania (Brand 1982). Emiliania and Gephyrocapsa species play an important role in geochemical cycles and knowledge of both intraand inter-specific genotypic variation is crucial to determine which species are the most important actors in, for example, the carbon cycle. Therefore, the develop- 
ment of specific markers to map the spatial and temporal variability of both $E$. huxleyi and Gephyrocapsa spp. remains an important target for future research.

\section{Syracosphaera pulchra (Plate 6)}

Syracosphaera pulchra is the most common member of the very diverse extant genus Syracosphaera and the only one to have been successfully isolated into culture (Inouye and Pienaar 1988). It occurs globally in all oceans (Okada and Honjo 1973; Okada and McIntyre 1977; Winter et al. 1994) and is common in sediments. Its first occurrence in the fossil record is in the early Pliocene at 4.8 Ma. This date is based on ODP Site 664 from analysis of the NEPTUNE database (Spencer-Cervato 1999) and was confirmed in the ODP reference slide collection at the Natural History Museum, London.

As $S$. pulchra coccospheres and coccoliths are very rich in morphological characters the species was regarded as very well defined and was selected as a key species for the CODENET project, in part to act as a control species to quantify the degree of intra-specific variation. The recent discovery of "pseudo-" cryptic species in S. pulchra (Geisen et al. 2002) however has shed a new light on this interpretation.

\section{Quantitative and qualitative morphology}

Coccospheres of the heterococcolith stage of S. pulchra are spherical to ellipsoidal and typically pear-shaped, a feature which is shared with the two associated holococcolithophores. The coccospheres are normally dithecate (i.e. show inner and outer layers of coccoliths with different morphologies) with dimorphic endothecal coccoliths (Figs. 1, 3). The cell bears two flagellae and a haptonema and the flagellar opening is surrounded by modified coccoliths possessing a spine which is forked at the end (Figs. 1, 2, 4). The elliptical body coccoliths have a corrugated wall with three external flanges (Fig. 3). The central area is formed of numerous radial laths that extend towards the centre of the coccolith and are partly joining (Figs. 3, 4). The monomorphic dome-shaped exothecal coccoliths are elliptical with a narrow central depression and slitted walls (Fig. 5). The heterococcolithophore species Syracosphaera pulchra contains two chloroplasts and exhibits two flagella.

For quantitative morphological analysis of the heterococcolith stage simple size measurements on body coccoliths have been performed. Data show a strong bi- to multimodality in samples from the fossil record and sediment trap material (Geisen et al. 2002). It was initially unclear whether this variation was due to genotypic or ecophenotypic variability. As cultures became available, these alternative hypotheses were tested by growing cultures under a range of environmental conditions. Morphometrical analyses performed on clonal cultures, revealed a strong unimodality, and no temperature related size variation was observed, indicating that the morphology is under strong genotypic control. 


\section{Life-cycles and holococcolith phase differentiation}

It has recently been demonstrated that the heterococcolithophore S. pulchra independently forms life-cycle associations with two holococcolithophores previously assigned to different genera, Calyptrosphaera oblonga and Daktylethra pirus (for a review refer to Cros et al. 2000; Geisen et al. 2002). Data here stem from observations both from a phase change observed in culture ( $S$. pulchra heterococcolith stage to " $D$. pirus" holococcolith stage) and from combination coccospheres in

Plate 6 Syracosphaera spp.

Fig. 1: SEM of a S. pulchra coccosphere. This typical specimen displays endothecal and exothecal coccoliths. Coccoliths surrounding the flagellar pole are spine bearing. Water sample, N. Atlantic., off the Canary Islands, R/V Poseidon cruise P233B, station 3.

Fig. 2: SEM of a $S$. pulchra coccosphere without exothecal coccoliths. Water sample, N. Atlantic, R/V Meteor cruise 42-4B, station US 1B.

Fig. 3: SEM of S. pulchra endothecal coccoliths. The specimen in lateral view shows the typical wall structure with three flanges. Note the lack of exothecal coccoliths. Water sample, N. Atlantic, off Canary Islands, R/V Meteor cruise 42-4B, station US 1B.

Fig. 4: SEM of a S. pulchra circumflagellar endothecal coccolith. Note the typical central spine with forked end. Water sample, N. Atlantic, off Canary Islands, R/V Meteor cruise 42-4B, station US 1B.

Fig. 5: SEM of a S. pulchra exothecal coccolith. Water sample, N. Atlantic, off Canary Islands, R/V Meteor cruise 42-4B, station US 1B.

Fig. 6: SEM of the holococcolithophore stage of S. pulchra. This stage was previously described as "Daktylethra pirus" and is referred to as S. pulchra HO pirus-type. Water sample, western Mediterranean, Alboran Sea, R/V Hesperides cruise MATER 2, station 69.

Fig. 7: SEM of a $S$. pulchra HO pirus-type circumflagellar holococcolith in lateral view. The circumflagellar coccoliths typically have a pointed hood. Note the clear offset between the hood and the base and the presence of perforations in the hood. Water sample, western Mediterranean, Alboran Sea, R/V Hesperides cruise MATER 2, station 69.

Fig. 8: SEM of $S$. pulchra HO pirus-type holococcoliths. The circumflagellar coccoliths typically have a pointed hood. Water sample, N. Atlantic, off Canary Islands, R/V Meteor cruise 42-4B, station US 1B.

Fig. 9: SEM of the holococcolithophore stage of S. pulchra. This stage was previously described as "Calyptrosphaera oblonga" and is referred to as S. pulchra HO oblonga-type. Water sample, N. Atlantic, off the Canary Islands, R/V Poseidon cruise P233B, station 3.

Fig. 10: SEM of a S. pulchra HO oblonga-type holococcolith. Note the hexagonal arrangement of the calcite rhombohedra and the absence of an offset between the hood and the base. Water sample, western Mediterranean, Alboran Sea, R/V Hesperides cruise MATER 2, station 69.

Fig. 11: SEM of S. pulchra HO oblonga-type circumflagellar holococcoliths. The circumflagellar coccoliths typically have a pointed hood. Water sample, western Mediterranean, Alboran Sea, R/V Hesperides cruise MATER 2, station 69.

Scale bars: Figs. 1, 2, 9: $5 \mu \mathrm{m}$, Fig. 6: $10 \mu \mathrm{m}$, Figs. 3, 4: $2 \mu \mathrm{m}$, Figs. 5, 7, 8, 10, $11: 1 \mu \mathrm{m}$. 
Species level variation in coccolithophores 341




water samples. Geisen et al. (2002) have concluded that this is an example of pseudo-cryptic speciation where morphological separation between the species is only visible in the haploid, holococcolith bearing stage. Although they infer that $S$. pulchra probably comprises two biological species it is currently impossible to separate them in the heterococcolith phase and so they introduced the informal terms $S$. pulchra HO pirus-type (Figs. 6-8) and S. pulchra HO oblonga-type (Figs. 9-11) until the heterococcolith phase can be discriminated. Re-examination of the morphometrical data from water samples and culture samples suggests that there may be a slight differentiation in the mean size of the endothecal heterococcoliths.

\section{Ecological, biogeographical and molecular separation}

The co-occurrence of the two holococcolithophores associated with S. pulchra in the same plankton samples has led to speculation about the nature of speciation and - comparable with the case of Emiliania - an ecological speciation can be hypothesised. Until now, however, the two Syracosphaera species can only be discriminated in their holococcolithophore stage and there is little information on their biogeographical and ecological ranges.

Thirteen clonal strains of S. pulchra are currently under molecular investigation to test the hypothesis of a slight differentiation in the mean size of the heterococcoliths between the two potential species. The 18S rDNA genes are strictly identical between the strains, but the first tufA DNA sequences show the presence of at least two different types. As for the other species described in this chapter, a comparison between genetic and morphological data will provide a powerful tool to discriminate which subtle morphological character(s) may allow distinction at the species level.

\section{Status of taxon}

In this case, heterococcolith morphology is remarkably complex and stable and $S$. pulchra had been regarded as a particularly well-defined species. Detailed study of geological and oceanographic samples however yielded more complex and variable morphological patterns than expected, but these were initially interpreted as essentially noise, i.e. random population-level variation. However, our observations of holococcolith-heterococcolith combination coccospheres and phase changes in cultured strains have indicated strong morphological differentiation in the haploid phase holococcoliths (Geisen et al. 2002). This discovery of cryptic species in $S$. pulchra has now severely challenged the interpretation of S. pulchra as a single species with a global occurrence. Until now any testing of the predictions arising from this has been critically dependent on the presence of the relatively rare holococcolithophores and hence biogeographical mapping of the two holococcolithophores involved remains an important target for future research. A further opportunity to solve this challenging problem will be the use of genetic markers to discriminate the two species. 


\section{Synthesis}

\section{Speciation and divergences (Plate 7)}

The set of morphotypes observed in each of the original species and the types of evidence which have lead us to infer that these are genotypically discrete are summarised in Plate 7. Each case is different but the obvious common feature is that taxa which have, with varying degrees of confidence, been regarded as single species prove to consist of a small set of separate species, even including our control species $S$. pulchra which was supposed to be unambiguously well-defined. Clearly this provides strong support for taxonomic splitting and suggests that current estimates of species level diversity in the coccolithophores are likely to be much too low. For biostratigraphy this is very positive since it indicates that fine scale morphological differences can legitimately be used. For Quaternary palaeocecological work there is strong potential for using the modern morphotypes to refine data retrieval (e.g. Bollmann et al. 2002). Implications for evolutionary understanding rather depend on divergence times and degree of differentiation of the taxa.

In a few cases our research has shown that fine-scale morphovariants of classic species in fact represent fully isolated species, which have diverged in the Pliocene (2-5 Ma) or earlier. For instance Umbilicosphaera sibogae, which by some authors has been subdivided into two varieties with alternative hypotheses that they represented ecotypes, life-cycle stages or closely related genotypes (Inouye and Pienaar 1984). Molecular evidence suggests that they have been genotypically independent for more than $5 \mathrm{Ma}$ according to the molecular clock of Sáez et al. (2003). Similarly, in modern Calcidiscus three morphotypes have been tentatively distinguished based on size variation and subtle morphological differences (Kleijne 1991, 1993; Knappertsbusch et al. 1997), but there has been uncertainty as to whether they intergrade or are discrete and hence whether they are ecophenotypes (Knappertsbusch 2000; Renaud and Klaas 2001). New data from plankton samples, life-cycle stages, culture studies and molecular genetic work all indicate that they in fact represent discrete species that probably diverged in the Middle Miocene (Geisen et al. 2002; Renaud et al. 2002; Sáez et al. 2003; Quinn et al. 2003). Similarly the Helicosphaera species, previously regarded as varieties of $H$. carteri, although only separated by slight morphological variation seem likely to have diverged in the Miocene, based on both geological record and molecular clock data. These results suggest that morphological differentiation can be strongly uncoupled from genetic divergences (see de Vargas et al. this volume, for more discussion on this aspect).

In contrast to these species which diverged long ago a second set of studied cases reveals another level of genotypical variability equally coupled with slight morphological variation. Among them are Emiliania huxleyi, Gephyrocapsa spp., Coccolithus spp., Calcidiscus quadriperforatus variants (see Quinn et al. this volume for a discussion on cryptic speciation in Calcidiscus quadriperforatus) and Syracosphaera pulchra, which reveal a similar pattern of variation, but there is 
evidence for more recent divergences. In each case divergence within the last 2 Ma and possibly much more recently seems likely. In these cases it is possible that we are dealing with ecologically separated sub-species rather than completely separate species.

These results indicate that, unless coccolithophores are currently undergoing an exceptional phase of radiative speciation, evolution is a dynamic process continuously producing and eliminating species. This process can be studied by a combination of morphological and molecular genetic methods (see Fig. 5 of de Vargas et al. this volume).

\section{Local adaptation a precursor of ecological speciation?}

Paasche (2002) synthesised a range of evidence to suggest that globally distributed species, such as E. huxleyi should be regarded as mosaics of locally adapted populations. Evidence includes: (a) genetic fingerprinting data for high levels of genetic recombination, within a haplo-diplontic life-cycle; (b) physiological experiments indicating genetic differentiation within populations and significant variation between environments (Brand 1981, 1982; Fisher and Honjo 1989; Young and Westbroek 1991; Paasche et al. 1996; Paasche 2002); (c) the very broad distribution of such species, occupying improbably wide ranges of habitats, contrasting with narrower ecological tolerances for individual culture isolates. To a certain extent our evidence, that the global species are in fact made up of a few separate species, constitutes an alternative explanation for the phenomenon of individual species having improbably wide geographic ranges and broad ecological tolerances. We did not study variation between strains of our redefined species in detail but our life-cycle data reinforce the importance of sexual reproduction in coccolithophores and preliminary AFLP studies of Calcidiscus (Saez unpublished data) confirmed high levels of differentiation within the separate species. So Paasche's model of extensive local adaptation is a possible origin of the numerous relatively recent divergences we have recognised. We suggest that this apparent local specialization may be a key factor for speciation in the coccolithophores, and possibly more generally for the evolutionary success of marine planktonic organisms.

\section{Outlook}

The current evidence of old speciations, recent divergences and local ecological adaptations, arguably intergrade - indeed it is often difficult to determine which pattern applies in a particular case. Hence a possible model is that local ecological adaptation leads to continuous evolution of new geographically restricted genetic varieties, which in certain cases differ sufficiently to form discrete sub-species that 


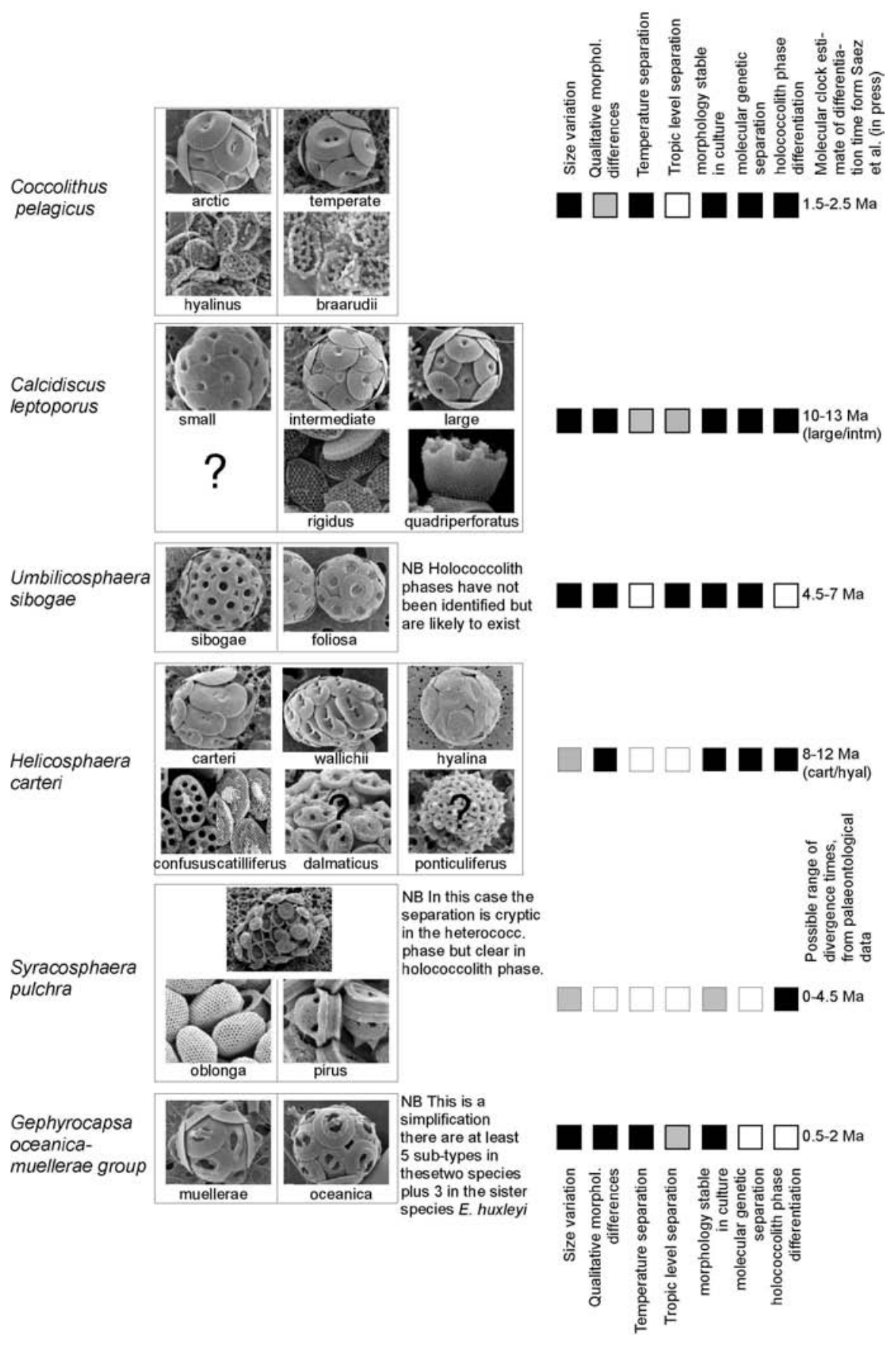


Plate 7. Outline of intra-specific variation in the CODENET taxa. Heterococcolith phases are illustrated above the holococcolith phases. Boxes indicate the type and the quality of available evidence to support the interpretation. Black boxes - strong data, grey boxes weak data, white boxes - no data.

disperse globally into similar ecological environments. A constant turnover of such sub-species may occur, possibly because of environmental change causing shifts in the extent of the ecological conditions to which they are adapted. If particular sub-species differentiate sufficiently both ecologically and genotypically, then they may diverge into discrete biological species.

A key factor to elucidate the underlying mechanisms of this hypothetical pattern of evolution is the understanding of the coccolithophore life-cycle and reproductive strategy. The presence of chloroplasts provides the algae with a seemingly unlimited source of energy. Unlike in other species however the energy produced is not stored in carbohydrates and fatty acids, but seems to maintain - in the presence of sufficient nutrients - a high biomass level by asexual reproduction (Smetacek 2001). This strategy might well be described as protection by outnumbering of possible predators, an extreme example being a phytoplankton bloom. The apparent decoupling of sexual recombination of genes and reproduction by mitotic fission allows for both rapid (local) differentiation and maintenance of high cell densities. Hence the ability to exchange genes within a population is an important - and in the case of the coccolithophores a long overlooked - tool for adaptation and speciation especially for planktonic organisms competing in a rapidly changing environment. As a logical consequence of this strategy it can be hypothesised that coccolithophores, which have lost or not evolved calcification in the haploid stage, might have an evolutionary advantage as this part of the lifecycle only occurs occasionally. Unlike in land plants, where the skeleton serves as a supporting structure in the competition of the chloroplasts for light (Smetacek 2001), this function seems unlikely for these minute marine planktonic algae living in near defiance of gravity. Hence mechanical protection against viruses and bacteria trying to enter the cell and against grazers with their mainly acidic stomachs (e.g. copepods) can be hypothesized as a function of coccoliths. However, protection for the relatively short time spent in the haploid stage is not needed and more energy is thus available for reproduction via mitosis. Important future research tasks will therefore focus on life-cycles and reproductive strategies of coccolithophores and will include the identification of possibly ecological triggers to induce phase changes.

Coccolithophores appear to show evidence for both classic models of evolution - phyletic gradualism and punctuated equilibria (allopatric speciation) (Eldredge 1971; Eldredge and Gould 1972; Gould and Eldredge 1977; Pearson 1993; Young and Bown 1994; Benton and Pearson 2001). We have demonstrated here that combining different strands of research can enable us to acquire detailed information on coccolithophore diversity and evolution and to gain further understanding of the underlying processes. 


\section{Acknowledgements}

This work is a contribution to the EU-funded TMR network CODENET (ERBFMRX CT97 0113) which funded IP, AGS and MG. Further funding was provided by the EU project Ironages (EVK2-CT-1999-00031), which supported MG. MG would particularly like to thank all the CODENET people for sharing and exchanging their ideas about coccolithophores. We would like to thank J. Giraudeau and an anonymous reviewer for their valuable comments which helped improve the quality of this manuscript.

\section{References}

Baumann K-H, Sprengel C (2000) Morphological variations of selected coccolith species in a sediment trap north of the Canary Islands. Journal of Nannoplankton Research 22: $185-193$

Baumann K-H, Andruleit H, Schröder-Ritzrau A, Samtleben C (1997) Spatial and temporal dynamics of coccolithophore communities during low production phases in the Norwegian-Greenland Sea. In: Hass HC, Kaminski MA (eds) Contributions to the Micropaleontology and Paleoceanography of the Northern North Atlantic. Grzybowski Foundation, pp 227-243

Baumann K-H, Young JR, Cachao M, Ziveri P (2000) Biometric study of Coccolithus pelagicus and its palaeoenvironmental utility. Journal of Nannoplankton Research 22: 82

Benton MJ, Pearson PN (2001) Speciation in the fossil record. Trends Ecol Evol 16: 405-411

Bollmann J (1997) Morphology and biogeography of Gephyrocapsa coccoliths in Holocene sediments. Mar Micropaleontol 29: 319-350

Bollmann J, Baumann K-H, Thierstein HR (1998) Global dominance of Gephyrocapsa coccoliths in the late Pleistocene: Selective dissolution, evolution, or global environmental change? Paleoceanography 13: 517-529

Bollmann J, Henderiks J, Brabec B (2002) Global calibration of Gephyrocapsa coccolith abundance in Holocene sediments for paleotemperature assessment. Paleoceanography 17: 7-1-7-9

Boudreaux JE, Hay WW (1969) Calcareous nannoplankton and biostratigraphy of the late Pliocene-Pleistocene-Recent sediments in the Submarex cores. Revta Esp Micropaleont 1: 249-292

Brand LE (1981) Genetic variability in reproduction rates in marine phytoplankton populations. Evolution 38: 1117-1127

Brand LE (1982) Genetic variability and spatial patterns of genetic differentiation in the reproductive rates of the marine coccolithophores Emiliania huxleyi and Gephyrocapsa oceanica. Limnol Oceanogr 27: 236-245

Bréhéret JG (1978) Formes nouvelles quaternaires et actuelles de la famille des Gephyrocapsaceae (Cocolithophorides). C R Acad Sci Série D 287: 447-449

Brown CW, Yoder JA (1993) Blooms of Emiliania huxleyi (Prymnesiophyceae) in surface waters of the Nova Scotian Shelf and the Grand Bank. J Plankton Res 15: 1429-1438 
Cachao M, Moita MT (2000) Coccolithus pelagicus, a productivity proxy related to moderate fronts off Western Iberia. Mar Micropaleontol 39: 131-155

Chepstow-Lusty A, Shackleton NJ, Backman J (1992) Upper Pliocene Discoaster abundance variations from the Atlantic, Pacific and Indian Oceans: the significance of productivity pressure at low latitudes. Memorie Sci geol 43: 357-373.

Cros L (2002) Planktic coccolithophores of the NW Mediterranean. PhD thesis, Universitat de Barcelona (ISBN 84-475-2680-1), p. 181

Cros L, Fortuño J-M (2002) Atlas of Northwestern Mediterranean Coccolithophores. Sci Mar 66: 7-182

Cros L, Kleijne A, Zeltner A, Billard C, Young JR (2000) New examples of holococcolithheterococcolith combination coccospheres and their implications for coccolithophorid biology. Mar Micropaleontol 39: 1-34

de Vargas C, Norris R, Zaninetti L, Gibb SW, Pawlowski J (1999) Molecular evidence of cryptic speciation in planktonic foraminifers and their relation to oceanic provinces. Proc natn Acad Sci USA 96: 2864-2868

Edvardsen B, Eikrem W, Green JC, Andersen RA, Yeo Moon-van der Staay S, Medlin LK (2000) Phylogenetic reconstructions of the Haptophyta inferred from $18 \mathrm{~S}$ ribosomal DNA sequences and available morphological data. Phycologia 39: 19-35

Eldredge N (1971) The allopatric model and phylogeny in Paleozoic invertebrates. Evolution 25: 156-167

Eldredge N, Gould SJ (1972) Punctuated equilibria: an alternative to phyletic gradualism. In: Schopf TJM (ed) Models in Paleobiology. Freeman, Cooper, and Co., San Francisco, pp 82-115

Findlay CS, Giraudeau J (2001) Extant calcareous nannoplankton in the Australian sector of the Southern Ocean (austral summers 1994 and 1995). Mar Micropaleontol 40: 417-439

Fisher NS, Honjo S (1989) Intraspecific differences in temperature and salinity responses in the coccolithophore Emiliania huxleyi. Biol Oceanogr 6: 355-361

Fresnel J (1994) A heteromorphic life cycle in two coastal coccolithophorids, $H y$ menomonas lacuna and Hymenomonas coronata (Prymnesiophyceae). Can J Bot 72: $1455-1462$

Fujiwara S, Tsuzuki M, Kawachi M, Minaka N, Inouye I (2001) Molecular phylogeny of the haptophyta based on the $r b c \mathrm{~L}$ gene and sequence variation in the spacer region of the RUBISCO operon. J Phycol 37: 121-129

Gartner S (1988) Paleoceanography of the Mid-Pleistocene. Mar Micropaleontol 13: 23-46

Gayral P, Fresnel J (1983) Description, sexualité et cycle développement d'une nouvelle coccolithophoracée (Prymnesiophiceae): Pleurochrysis pseudoroscoffensis sp. nov. Protistologica 19: 245-261

Geisen M (2003) Studies on the species level variation of selected coccolithophores. $\mathrm{PhD}$ thesis, University College London, p. 199

Geisen M, Billard C, Broerse ATC, Cros L, Probert I, Young JR (2002) Life-cycle associations involving pairs of holococcolithophorid species: intraspecific variation or cryptic speciation? Eur J Phycol 37: 531-550

Geitzenauer KR, Roche MB, McIntyre A (1977) Coccolith biogeography from North Atlantic and Pacific surface sediments. Acad. Press, London, New York, San Francisco

Gould SJ, Eldredge N (1977) Punctuated equilibria: the tempo and mode of evolution reconsidered. Paleobiology 3: 115-151 
Hagino K, Okada H (2001) Morphological observations of living Gephyrocapsa crassipons. Journal of Nannoplankton Research 23: 3-7

Hay WW, Beaudry FM (1973) Calcareous nannofossils - Leg 15. In: Edgar NT, Saunders JB (eds) Initial Reports of the DSDP, Leg 15, pp 625-684

Hay W W, Mohler H P, Roth P H, Schmidt R R, Boudreaux J E (1967) Calcareous nannoplankton zonation of the Cenozoic of the Gulf Coast and Caribbean-Antillean area, and transoceanic correlation. Trans Gulf Cst Ass geol Socs 17: 428-480

Holligan PM, Fernández JA, Balch WM, Boyd P, Burkill PH, Finch M, Groom SB, Malin G, Müller K, Purdie DA, Robinson C, Trees CC, Turner SM, van der Wal P (1993) A biogeochemical study of the coccolithophore, Emiliania huxleyi, in the North Atlantic. Global Biochem Cy 7: 879-900

Iglesias-Rodríguez MD, Brown CW, Doney SC, Kleypas JA, Kolber D, Kolber Z, Hayes PK, Falkowski PG (2002a) Representing key functional groups in ocean carbon cycle models: Coccolithophorids. Global Biochem Cy 16: 47/41-47/20

Iglesias-Rodríguez MD, Sáez AG, Groben R, Edwards KJ, Batley J, Medlin LK, Hayes PK (2002b) Polymorphic microsatellite loci in global populations of the marine coccolithophorid Emiliania huxleyi. Mol Ecol Notes 2: 495-497

Inouye I, Pienaar RN (1984) New observations on the coccolithophorid Umbilicosphaera sibogae var. foliosa (Prymnesiophyceae) with reference to cell covering, cell structure and flagellar apparatus. Br phycol J 19: 357-369

Inouye I, Pienaar RN (1988) Light and electron microscope observations of the type species of Syracosphaera, S. pulchra (Prymnesiophyceae). Br phycol J 23: 205-217

Jafar SA, Martini E (1975) On the validity of the calcareous nannoplankton genus Helicosphaera. Senckenberg leth 56: 381-397

Jordan RW, Chamberlain AHL (1997) Biodiversity among haptophyte algae. Biodivers Conserv 6: 131-152

Jordan RW, Green JC (1994) A check-list of the extant haptophyta of the world. J mar biol Ass U K 74: 149-174

Jordan RW, Kleijne A (1994) A classification system for living coccolithophores. In: Winter A, Siesser WG (eds) Coccolithophores. Cambridge University Press, Cambridge, pp 83-105

Jordan RW, Young JR (1990) Proposed changes to the classification system of living Coccolithophorids. Int Nannoplankton Assoc Newsl 1: 15-18

Kamptner E (1927) Beitrag zur Kenntnis adriatischer Coccolithophoriden. Arch Protistenkd 58: $173-184$

Kamptner E (1943) Zur Revision der Coccolithineen-Spezies Pontosphaera huxleyi Lohm. Anz Akad Wiss Wien 80: 73-49

Kamptner E (1956) Das Kalkskelett von Coccolithus huxleyi (Lohmann) Kamptner und Gephyrocapsa oceanica Kamptner (Coccolithineae). Arch Protistenkd 101: 171-202

Kamptner E (1963) Coccolithineen-Skelettreste aus Tiefseeablagerungen des Pazifischen Ozeans. Annln naturh Mus Wien 66: 139-204

Kleijne A (1991) Holococcolithophorids from the Indian Ocean, Red Sea, Mediterranean Sea and North Atlantic Ocean. Mar Micropaleontol 17: 1-76

Kleijne A (1993) Morphology, taxonomy and distribution of extant coccolithophorids (Calcareous nannoplankton). PhD thesis, Free University Amsterdam (ISBN 90-90061614), p. 321 
Knappertsbusch M (1997) Morphologic variability of the coccolithophorid Calcidiscus leptoporus in the plankton, surface sediments and from the Early Pleistocene. Mar Micropaleontol 30: 293-317

Knappertsbusch M, Cortés, Thiersstein HR (2000) Morphological evolution of the coccolithophorid Calcidiscus leptoporus from the Early Miocene to recent. J Paleontol 74: 712-730

Knowlton N (1993) Sibling species in the sea. A rev ecol syst 24: 189-216

Loeblich AR, Tappan H (1966) Annotated index and bibliography of the calcareous nannoplankton. Phycologia 5: 81-216

Lohmann H (1902) Die Coccolithophoridae, eine Monographie der Coccolithen bildenden Flagellaten, zugleich ein Beitrag zur Kenntnis des Mittelmeerauftriebs. Arch Protistenkd 1: 89-165

Matsuoka H, Okada H (1989) Quantitative Analysis of Quaternary Nannoplankton in the Subtropical Northwestern Pacific Ocean. Mar Micropaleontol 14: 97-118

Matsuoka H, Okada H (1990) Time-progressive morphometric changes of the genus Gephyrocapsa in the Quaternary sequence of the tropical Indian Ocean, Site 709. In: Duncan RA, Backman J, Peterson LC (eds) Proc ODP, Sci Results, College Station, pp $255-270$

McIntyre A, Bé AWH (1967) Modern Coccolithophoridae of the Atlantic Ocean - I. Placoliths and Cyrtholiths. Deep-Sea Res 14: 561-597

Medlin LK, Barker GLA, Green JC, Hayes DE, Marie D, Wrieden S, Vaulot D (1996) Genetic characterization of Emiliania huxleyi (Haptophyta). J Mar Syst 9: 13-32

Medlin LK, Kooistra WHCF, Potter D, Saunders JB, Andersen RA (1997) Phylogenetic relationships of the "golden algae" (haptophytes, heterokont chromophytes) and their plastids. Pl Syst Evol Suppl 11: 187-219

Mueller UG, LaReesa Wolfenbarger L (1999) AFLP genotyping and fingerprinting. Trends Ecol Evol 14: 389-394

Nishida S (1971) Nannofossils from Japan IV. Calcareous nannoplankton fossils from the Tonohama Group, Shikoki, southwest Japan. Trans Proc palaeont Soc Japan 83: $143-161$

Nishida S (1979) Atlas of Pacific Nannoplanktons. News Osaka Micropaleontol Special Paper: $1-31$

Okada H, Honjo S (1973) The distribution of oceanic coccolithophorids in the Pacific. Deep-Sea Res 20: 355-374

Okada H, McIntyre A (1977) Modern coccolithophores of the Pacific and North Atlantic Oceans. Micropaleontology 23: 1-55

Okada H, McIntyre A (1979) Seasonal distribution of modern coccolithophores in the Western North Atlantic Ocean. Mar Biol Berlin 54: 319-328

Paasche E (2002) A review of the coccolithophorid Emiliania huxleyi (Prymnesiophyceae), with particular reference to growth, coccolith formation, and calcificationphotosynthesis interactions. Phycologia 40: 503-529

Paasche E, Brubak S, Skattebol S, Young JR, Green JC (1996) Growth and calcification in the coccolithophorid Emiliania huxleyi (Haptophyceae) at low salinities. Phycologia 35: 394-403

Parke M, Adams I (1960) The motile (Crystallolithus hyalinus Gaarder \& Markali) and non-motile phases in the life history of Coccolithus pelagicus (Wallich) Schiller. J mar biol Ass U K 39: 263-274 
Pearson PN (1993) A lineage phylogeny for the Paleogene planktonic foraminifera. Micropaleontology 39: 193-232

Perch-Nielsen K (1985) Cenozoic calcareous nannofossils. In: Bolli HM, Saunders JB, Perch-Nielsen K (eds) Plankton Stratigraphy. Cambridge University Press, Cambridge, pp 427-555

Pujos A (1985) Quaternary nannofossils from the Goban Spur, eastern North Atlantic Ocean DSDP Holes 548-549A. Initial Reports of the DSDP. U.S. Government Printing Office, Washington, pp 767-792

Quinn P, Thierstein HR, Brand LE, Winter A (2003) Experimental evidence for the species character of Calcidiscus leptoporus morphotypes. J Paleontol 77 (5): 825-830

Rayns DG (1962) Alternation of generations in a coccolithophorid, Cricosphaera carterae (Braarud \& Fragerl.) Braarud. J mar biol Ass U K 42: 481-484

Renaud S, Klaas C (2001) Seasonal variations in the morphology of the coccolithophore Calcidiscus leptoporus off Bermuda (N. Atlantic). J Plankton Res 23: 779-795

Renaud S, Ziveri P, Broerse ATC (2002) Geographical and seasonal differences in morphology and dynamics of the coccolithophore Calcidiscus leptoporus. Mar Micropaleontol 46: 363-385

Rowson JD, Leadbeater BSC, Green JC (1986) Calcium carbonate deposition in the motile (Crystallolithus) phase of Coccolithus pelagicus (Prymnesiophyceae). Br phycol J 21: 359-370

Sáez AG, Probert I, Geisen M, Quinn P, Young JR, Medlin LK (2003) Pseudo-cryptic speciation in coccolithophores. Proc natn Acad Sci USA 100: 7163-7168

Samtleben C (1980) Die Evolution der Coccolithophoriden-Gattung Gephyrocapsa nach Befunden im Atlantik. Palaeont Z 54: 91-127

Samtleben C, Bickert T (1990) Coccoliths in sediment traps from the Norwegian Sea. Mar Micropaleontol 16: 36-64

Samtleben C, Schröder A (1992) Living coccolithophore communities in the NorwegianGreenland Sea and their record in sediments. Mar Micropaleontol 19: 333-354

Smetacek V (2001) A watery arms race. Nature 411: 745

Spencer-Cervato C (1999) The Cenozoic deep sea microfossil record: explorations of the DSDP/ODP sample set using the Neptune database. Palaeontologica Electronica 2: $1-268$

Theodoridis S (1984) Calcareous nannofossil biostratigraphy of the Miocene and revision of the helicoliths and discoasters. Utrecht micropaleont Bull 32: 1-271

Thierstein HR, Geitzenauer KR, Molfino B, Shackleton NJ (1977) Global synchroneity of late Quaternary coccolith datum levels: Validation by oxygen isotopes. Geology 5: 400-404

Wallich GC (1877) Observations on the coccosphere. Ann Mag nat Hist 19: 342-350

Wei W (1993) Calibration of Upper Pliocene - Lower Pleistocene nannofossil events with oxygen isotope stratigraphy. Paleoceanography 8: 85-99

Wei W, Shilan Z (1996) Taxonomy and magnetobiochronology of Tribrachiatus and Rhomboaster, two genera of calcareous nannofossils. J Paleontol 70: 7-22

Westbroek P, Young JR, Linschooten K (1989) Coccolith production (Biomineralization) in the marine alga Emiliania huxleyi. J Protozool 36: 368-373

Westbroek P, Brown CW, van Bleijswijk J, Brownlee C, Brummer G-JA, Conte M, Egge J K, Fernandez E, Jordan RW, Knappertsbusch M, Stefels J, Veldhuis MJW, van der Wal P, Young JR (1993) A model system approach to biological climate forcing. The example of Emiliania huxleyi. Global Planet Change 8: 27-46 
Westbroek P, van Hinte JE, Brummer G-JA, Veldhuis MJW, Brownlee C, Green JC, Harris R, Heimdal BR (1994) Emiliania huxleyi as a key to biosphere-geosphere interactions. In: Green JC, Leadbeater BSC (eds) The Haptophyte Algae. Clarendon Press, Oxford, pp 321-334

Winter A, Siesser WG (1994) Atlas of living coccolithophores. In: Winter A, Siesser WG (eds) Coccolithophores. Cambridge University Press, Cambridge, pp 107-159

Winter A, Jordan RW, Roth PH (1994) Biogeography of living coccolithophores in ocean waters. In: Winter A, Siesser WG (eds) Coccolithophores. Cambridge University Press, Cambridge, pp 161-177

Young JR (1991) A Quarternary nannofossil range chart. Int Nannoplankton Assoc Newsl 13: $14-17$

Young JR (1994) Variation in Emiliania huxleyi coccolith morphology in samples from the Norwegian EHUX experiment, 1992. Sarsia 79: 417-425

Young JR (1998) Neogene. In: Bown PR (ed) Calcareous Nannofossil Biostratigraphy. Chapman \& Hall, London, pp 225-265

Young JR, Bown PR (1994) Palaeontological perspectives. In: Green JC, Leadbeater BSC (eds) The Haptophyte Algae. Clarendon Press, Oxford

Young JR, Westbroek P (1991) Genotypic variation in the coccolithophorid species Emiliania huxleyi. Mar Micropaleontol 18: 5-23

Young JR, Didymus JM, Bown PR, Prins B, Mann S (1992) Crystal assembly and phylogenetic evolution in heterococcoliths. Nature 356: 516-518

Young JR, Davis SA, Bown PR, Mann S (1999) Coccolith ultrastructure and biomineralisation. J struct Biol 126: 195-215 